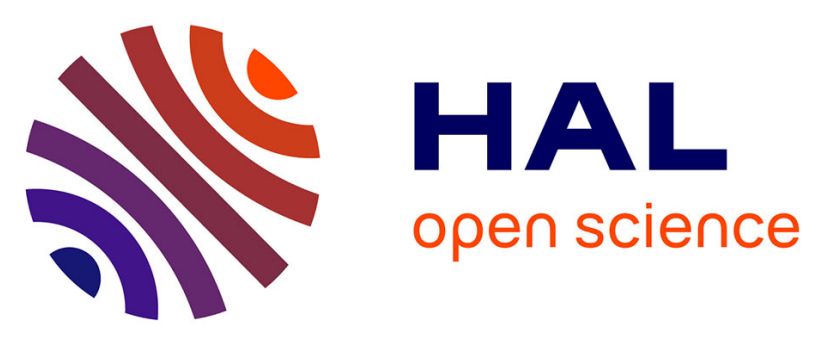

\title{
Influence of silica functionalization on water sorption and thermochemical heat storage of mesoporous SBA-15/ CaCl 2 composites
}

Lishil Silvester, Quentin Touloumet, Aiman Kamaruddin, Fernand

Chassagneux, Georgeta Postole, Aline Auroux, Laurence Bois

\section{To cite this version:}

Lishil Silvester, Quentin Touloumet, Aiman Kamaruddin, Fernand Chassagneux, Georgeta Postole, et al.. Influence of silica functionalization on water sorption and thermochemical heat storage of mesoporous SBA-15/CaCl 2 composites. ACS Applied Energy Materials, 2021, 10.1021/acsaem.1c00786 . hal-03245878

\section{HAL Id: hal-03245878 \\ https://hal.science/hal-03245878}

Submitted on 2 Jun 2021

HAL is a multi-disciplinary open access archive for the deposit and dissemination of scientific research documents, whether they are published or not. The documents may come from teaching and research institutions in France or abroad, or from public or private research centers.
L'archive ouverte pluridisciplinaire HAL, est destinée au dépôt et à la diffusion de documents scientifiques de niveau recherche, publiés ou non, émanant des établissements d'enseignement et de recherche français ou étrangers, des laboratoires publics ou privés. 


\section{Influence of silica functionalization on water}

\section{sorption and thermochemical heat storage of}

\section{mesoporous $\mathrm{SBA}-15 / \mathrm{CaCl}_{2}$ composites}

Lishil Silvester $^{a, *}$, Quentin Touloumet $^{b}$, Aiman Kamaruddin $^{b}$, Fernand Chassagneux $^{a}$, Georgeta Postole $^{b}$, Aline Auroux ${ }^{b}$, Laurence Bois ${ }^{a, *}$

${ }^{a}$ Université Claude Bernard-Lyon 1, LMI, CNRS UMR 5615, 69622, Villeurbanne, France

${ }^{\mathrm{b}}$ Univ Lyon, Université Claude Bernard Lyon 1, CNRS, IRCELYON, F-69626, Villeurbanne, France

KEYWORDS Thermochemical heat storage, mesoporous silica, $\mathrm{CaCl}_{2} \cdot \mathrm{nH}_{2} \mathrm{O}$, dehydration /hydration cycles, water sorption kinetics, TGA/DSC.

ABSTRACT. SBA- $\mathrm{CaCl}_{2}$ (SCa) composites with high $\mathrm{CaCl}_{2}$ content were prepared using the non-functionalized and the methyl- and carboxyl- functionalized mesoporous SBA-15 supports and their thermochemical heat storage (TCHS) performance have been investigated using a TG/DSC system coupled with a humidity generator. This paper presents the influence of silica (SBA-15) functionalization on the structural-textural properties of $\mathrm{SCa}$ composites and consequently on their water sorption and heat storage performances. All SCa composites exhibited enhanced water uptake compared to the pure $\mathrm{CaCl}_{2}$ due to the well dispersion of salt 
particles in the SBA pores. Non-functionalized composite demonstrated highest water sorption rate and heat storage capacity compared to all functionalized composites. The Fickian rate constant $(\mathrm{k})$ and conversion rate $(\mathrm{d} \alpha / \mathrm{dt})$ determined for the hydration cycles revealed that the water sorption rate of the $\mathrm{SCa}$ composites is mainly controlled by the intrinsic reaction between the salt particles and water. Best performing non-functionalized composite exhibited stable heat storage capacity $\left(317 \pm 6 \mathrm{~kJ} \mathrm{~mol}^{-1} \mathrm{CaCl}\right)$ and hydration rate $\left(7 \pm 0.15 \times 10^{-5} \mathrm{~s}^{-1}\right)$ for five successive hydration cycles at $30 \%$ relative humidity $(\mathrm{RH})$.

\section{Introduction}

For the past few years, there is an increasing interest in the renewable energy storage materials not only because they can reduce the consumption of fossil fuel energy and global warming but also, they can facilitate the use of potential renewable energy sources that still remain unexplored. For example, out of $\sim 20 \%$ of the total renewable energy, the consumption/storage of most abundant solar energy is less than $0.5 \% .{ }^{1}$ Overall, the sun emits about 7,000 times more energy than is required for human consumption. At present, the total amount of solar energy consumed for human use is less than $1 \%$ of our entire energy requirements. This means that enormous energy is still waiting to be captured. ${ }^{2}$ There are two main technologies to harness solar energy: photovoltaic solar technology and solar thermal technology. While the former is a well-known and extensively used technology that directly converts sunlight into electricity, the later one is still an emerging technology used to store the heat energy. Considering the fact that most fraction of the solar energy remains unused despite of its intermittent availability, there is an overwhelming necessity to develop technologies that can store solar energy effectively in the form of thermal energy. 
Thermal energy can be usually stored in materials with tunable internal energy. Depending on how the thermal energy is stored, there are three types of storage: Sensible heat storage (SHS), Latent heat storage (LHS) and Thermochemical heat storage (TCHS) ${ }^{3-5}$ TCHS system mainly consists of a sorption material (sorbent) and a sorbate (mostly water). It works on the principle that sorbent releases water when heated (charging) and releases heat (discharging) by uptaking water vapor. Hence, a good TCHS system should contain sorbent materials that are capable of not only storing sufficient amount of heat during the dehydration step but also possess adequate water sorption capacity during the hydration step. While the porous solids like silica gel and zeolite exhibited moderate heat storage capacity due to their water adsorption ability, the salts like $\mathrm{CaCl}_{2}, \mathrm{MgCl}_{2}, \mathrm{LiCl}$ etc...demonstrated even higher heat storage capacity resulting from their large affinity for water and subsequent salt-water reaction. ${ }^{6-10}$ The TCHS performances of inorganic salts like $\mathrm{CaCl}_{2}, \mathrm{MgCl}_{2}, \mathrm{MgSO}_{4}, \mathrm{Ba}(\mathrm{OH})_{2}, \mathrm{LiNO}_{3}, \mathrm{Al}\left(\mathrm{SO}_{4}\right)_{3}$ etc... have been studied and their energy storage density have been measured between 1 and $3 \mathrm{GJ} \cdot \mathrm{m}^{-3} \cdot{ }^{6-13}$ However, most of these pure salts showed poor performance with a loss of energy storage capacity and stability due to the agglomeration of salt particles, crust formation blocking water diffusion and slow kinetics. When pure $\mathrm{CaCl}_{2}, \mathrm{Ba}(\mathrm{OH})_{2}$ and $\mathrm{Al}_{2}\left(\mathrm{SO}_{4}\right)_{3}$ salts were used as a TCHS material, a loss of $37 \%, 44 \%$ and $80 \%$ of energy density respectively was observed after the first dehydration/hydration cycle. ${ }^{11,12}$

In order to overcome the aforementioned issues of using mere salts, several porous solids such as mesoporous silicas (SBA-15 \& MCM-41) $)^{12}$, alumina $^{13}$, silica-alumina ${ }^{11}$, zeolites ${ }^{14}$, Metal organic frameworks $(\mathrm{MOFs})^{15}$ and siloxane foams ${ }^{16}$ were used as host matrix to incorporate salts. The matrix can be an adsorbent with some heat storage capacity such as zeolites or an adsorptive material with good heat and mass transfer properties such as carbons or metal 
foams. ${ }^{10}$ Also, the adsorption properties of a salt may be modified by dispersing it in the porous solids with different material types and pore sizes. ${ }^{10}$ Hence, the use of appropriate porous host matrix should help to: accommodate large quantity of salts, enhance the salt dispersion, stabilize the salts, facilitates the adsorption/diffusion of water and improve the heat storage capacity. However, the investigated matrices often suffer from their rigidity as they are submitted to forces due to the salt solution expansion occurring during rehydration. ${ }^{16}$ Encapsulation of the salts is a way to stabilize them as observed in the mesoporous silica shell composite. ${ }^{17}$

Composites based on $\mathrm{CaCl}_{2}$ salt are largely studied because of their comparatively lower deliquescence relative humidity (DRH) $\left(\sim 29 \%\right.$ at $\left.\mathrm{T}=25^{\circ} \mathrm{C}\right)$ and reasonable enthalpy of hydration values compared to other salts that permit its usage in real life applications carried out at ambient conditions (lower relative humidity $\sim 30 \%$ at $\mathrm{T}=25^{\circ} \mathrm{C}$ ). ${ }^{18} \mathrm{In}$ addition to the anhydrous $\mathrm{CaCl}_{2}$ phase, the hydrated forms such as $\mathrm{CaCl}_{2} \cdot 0.3 \mathrm{H}_{2} \mathrm{O}, \mathrm{CaCl}_{2} \cdot \mathrm{H}_{2} \mathrm{O}, \mathrm{CaCl}_{2} \cdot 2 \mathrm{H}_{2} \mathrm{O}, \mathrm{CaCl}_{2} \cdot 4 \mathrm{H}_{2} \mathrm{O}$ and $\mathrm{CaCl}_{2} \cdot 6 \mathrm{H}_{2} \mathrm{O}$ have been reported. ${ }^{18-22}$ Among the composites studied, silica is one of the host matrices that have been widely used to incorporate the $\mathrm{CaCl}_{2}$ salt. Dawoud et al studied the water sorption capacity and kinetics of silica gel- $\mathrm{CaCl}_{2}$ composites in sorption heat pump conditions and reported higher performance of microporous silica compared to mesoporous silica though the sorption kinetics was slower on the former. ${ }^{23}$ In contrast, Zheng et al reported that $\mathrm{CaCl}_{2}$ composite of mesoporous silica gel has high water sorption capacity and sorption rate. ${ }^{24}$ The mesoporous silica gel composite with $35 \mathrm{wt} . \% \mathrm{CaCl}_{2}$ exhibited excellent stability in low grade heat storage applications during 500 cycles. ${ }^{25}$ The results of the study using silica-activated carbon composite with $30 \mathrm{wt} . \% \mathrm{CaCl}_{2}$ demonstrated a specific cooling power of $\sim 1361{\mathrm{~kJ} . \mathrm{kg}^{-1}}^{-1}$ that outperforms commonly used single adsorbents in solar adsorption cooling systems. ${ }^{26}$ When all the aforementioned $\mathrm{CaCl}_{2} /$ silica composites were prepared to study different applications, 
Courbon et al prepared $43 \mathrm{wt} . \% \mathrm{CaCl}_{2}$-silica gel composite to study their performance in TCHS application. ${ }^{27}$ They reported a cycle loading lift of $0.40 \mathrm{~g} . \mathrm{g}^{-1}$ that corresponds to an energy

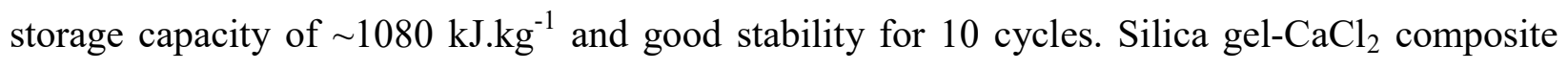
showed better performance in terms of heat $\left(746 \mathrm{~kJ} . \mathrm{kg}^{-1}\right)$ and water uptake capacity $\left(0.27 \mathrm{~g} . \mathrm{g}^{-1}\right)$ among all $\mathrm{CaCl}_{2}$ composites ( $\sim 14$ to 15 wt.\%) based on silica gel, alumina and bentonite. ${ }^{13}$ Jabbari-Hichri et al reported that the heat storage capacity was enormously increased by incorporating $\mathrm{CaCl}_{2}$ in silica-alumina $\left(\sim 1178 \mathrm{~kJ} \mathrm{~kg}^{-1}\right.$ for 24.4 wt.\% $\left.\mathrm{CaCl}_{2}\right)$ host matrix compared to pure silica-alumina $\left(448 \mathrm{~kJ} \cdot \mathrm{kg}^{-1}\right) .{ }^{11}$ They reported the formation of surface layer of salt on silica-alumina composite that improves the hydration of salt without any dissolution of the salt. Calcium chloride salt after microencapsulation with ethyl cellulose showed high multi cyclic stability and faster kinetics compared to its pure and impregnated counterparts. ${ }^{28}$ A 62 wt.\% $\mathrm{CaCl}_{2}$ composite based on MIL-101(Cr) showed higher energy storage capacity ( 1746 kJ.kg-1) and stability during 10 cycles compared to silica gel-based composites for space heating applications. ${ }^{15}$ Heat storage densities can reach around $0.65 \mathrm{GJ} . \mathrm{m}^{-3}$ in silica porous $\operatorname{composites}^{13,27}, 1 \mathrm{GJ}^{-3}$ in MOF matrix ${ }^{15}$ and $0.86 \mathrm{GJ}^{-3} \mathrm{~m}^{-3}$ in a high performing salt encapsulated in mesoporous silica shell composite. ${ }^{16}$

SBA-15 is known to possess ordered mesopores, high pore volume and large surface area and has a huge potential as a host to accommodate adequate amount of salt and enhances water uptake. Studies have been reported on the use of $\mathrm{SBA}-\mathrm{CaCl}_{2}$ composites for thermochemical heat storage. ${ }^{12,13,29-35}$ The high water sorption capacity $\left(0.47 \mathrm{g.g}^{-1}\right.$ at $\left.\mathrm{P} / \mathrm{P}_{0}<0.3\right)$ of SBA$15 / \mathrm{CaCl}_{2}$ composites was first evidenced by Ponomarenko et al. ${ }^{30,31}$ They reported that the tuning of pore size $(8-15 \mathrm{~nm})$ affects the water sorption properties of $\mathrm{SBA}-15 / \mathrm{CaCl}_{2}$ composites. When the particles are dispersed in smaller pores $(8 \mathrm{~nm})$, hydration occurs rapidly and the 
melting occurs at lower temperature. ${ }^{30,31}$ The evolution of such composites after water adsorption has been studied by Ristic et al with salt content comprised between 4 and $20 \mathrm{wt} . \% .{ }^{32}$ The use of composite $\mathrm{SBA}-15 / \mathrm{CaCl}_{2}$ as phase change materials have also been recently studied. ${ }^{33-35}$ The melting temperature of the $\mathrm{CaCl}_{2} \cdot 6 \mathrm{H}_{2} \mathrm{O}$ salt decreases when salt is mixed with mesoporous silica. ${ }^{33}$ Calcium chloride has also been used to obtain composites in mesoporous silica as molten salt for high temperature heat storage applications. ${ }^{34,35}$ The sorption properties of the calcium chloride composites can be related to the hydrophobic character of the host and can also depend of the salt-host interactions. Though $\mathrm{CH}_{3}$ - functionalization of SBA-15 can have significant influence on the hydrophobic nature of the solids and also on the water sorption behaviour of the solids, its impact towards the TCHS behaviour has never been investigated. Carboxylic functionalization of SBA-15 can modify the salt-matrix interactions as carboxylic groups may coordinate with calcium ions and its influence on composite properties has never been reported. In this study, we prepared methyl- and carboxyl- groups functionalized SBA- $15 / \mathrm{CaCl}_{2}$ composites with higher $\mathrm{CaCl}_{2}$ content $(\sim 60$ wt.\%) than similar host-guest composites so far reported. Our main objective is to gain insight on the impact of the chemical modification of the mesoporous silica walls with methyl or carboxylic groups on the dehydration/hydration behaviours of the salt when it is confined inside the silica mesopores. The influence of functionalization on the structural-textural properties of the composites has been investigated in detail. Their TCHS performances were examined using the thermogravimetric analysis (TGA)differential scanning calorimetry (DSC) unit coupled with a controlled humidity generator. This instrument permits simultaneous measurement of the mass change and the heat variations of a sample at controlled relative humidity. Hence, it is employed to study the water sorption and TCHS behaviours of the composites during multiple hydration/dehydration cycles. ${ }^{910,26,34,35}$ 


\section{Experimental methods}

\subsection{Syntheses of $\mathrm{SBA}-15 / \mathrm{CaCl}_{2}$ composites}

Table 1. Syntheses protocols of SBA- $15 / \mathrm{CaCl}_{2}$ composites

\begin{tabular}{lccc}
\hline Solids & $\begin{array}{c}\text { Pre- } \\
\text { functionalization }^{\text {a }}\end{array}$ & $\begin{array}{c}\text { Post- } \\
\text { functionalization }^{\mathbf{b}}\end{array}$ & $\begin{array}{c}\text { Theoretical } \\
\text { amount of }^{\text {anhydrous CaCl}} \\
\left(\mathbf{w t} \% \mathbf{C}^{\mathbf{c}}\right.\end{array}$ \\
\hline Ca* & - & - & 76 \\
SBA-15 & - & - & 0 \\
SCa1 & - & - & 62 \\
SCa2 & HMD & - & 62 \\
SCa3 & - & HMDS & 62 \\
SCa4 & CES & - & 62 \\
\hline
\end{tabular}

\footnotetext{
*Pure $\mathrm{CaCl}_{2} \cdot 2 \mathrm{H}_{2} \mathrm{O}$ salt used to prepare composites

${ }^{a}$ Functionalization of SBA-15 is performed before $\mathrm{CaCl}_{2}$ impregnation, using HMDS (hexamethyldisilazane) or CES (carboxyethylsilanetriol) to graft $\left(\mathrm{CH}_{3}\right)_{3} \mathrm{Si}$ - and carboxylic groups respectively.

${ }^{\mathrm{b}}$ Functionalization of SBA-15 is performed after impregnation of $\mathrm{CaCl}_{2}$

${ }^{\mathrm{c}}$ Amount based on $1.5 \mathrm{mmol}$ of $\mathrm{CaCl}_{2}$ for $1.66 \mathrm{mmol}$ of silica used to prepare the composites. The wt.\% of anhydrous $\mathrm{CaCl}_{2}$ present in the pure $\mathrm{CaCl}_{2} \cdot 2 \mathrm{H}_{2} \mathrm{O}$ is calculated by considering their molar masses $\left(111 \mathrm{~g} \cdot \mathrm{mol}^{-1}\right.$ for $\mathrm{CaCl}_{2}$ and $147 \mathrm{~g} \mathrm{~mol}^{-1}$ for $\mathrm{CaCl}_{2} \cdot 2 \mathrm{H}_{2} \mathrm{O}$ )
}

Reagent grade chemicals Tetraethoxysilane (99.9\%, abcr $\mathrm{GmbH} \& \mathrm{Co})$, Pluronic P123 (Poly(ethylene oxide)-poly(propylene oxide)-poly(ethylene oxide), FW = 8400, Aldrich), $\mathrm{HCl}$ (37\%, Carlo Erba), hexamethyldisilazane (HMDS) (> 98\%, Fluka), carboxyethylsilanetriol disodium salt (CES) $\left(25 \%\right.$ in $\mathrm{H}_{2} \mathrm{O}$, abcr $\left.\mathrm{GmbH} \& \mathrm{Co}\right)$ and $\mathrm{CaCl}_{2} .2 \mathrm{H}_{2} \mathrm{O}(99.0 \%$, Alfa Aesar) were used to synthesis mere SBA-15 and HMDS (methyl group) or CES (carboxyl group) functionalized $\mathrm{SBA}-\mathrm{CaCl}_{2}$ composites. The well-ordered hexagonal mesoporous silica (SBA-15) sample was prepared using the poly(ethylene oxide)-poly-(propylene oxide)-poly(ethylene oxide) triblock copolymer (Pluronic P123, BASF) as the surfactant and tetraethylorthosilicate 
(TEOS) as the silica source. ${ }^{37}$ The surfactant P123 $(4 \mathrm{~g})$ is dissolved in $30 \mathrm{~mL}$ of water and added in $120 \mathrm{~mL} \mathrm{HCl}(2 \mathrm{M})$ solution at $35^{\circ} \mathrm{C}$. TEOS $(8.5 \mathrm{~g})$ is then added to the micellar solution and the mixture is stirred for $24 \mathrm{~h}$ at $35^{\circ} \mathrm{C}$. After this step, a hydrothermal treatment at $100^{\circ} \mathrm{C}$ is done for $24 \mathrm{~h}$. The material was recovered by filtration, washed with water, dried and calcined in a furnace at $550^{\circ} \mathrm{C}$ for $5 \mathrm{~h}$. Pre- (before $\mathrm{CaCl}_{2}$ addition) and post- (after $\mathrm{CaCl}_{2}$ addition) functionalization's with HMDS of SBA-15 and SBA-15/CaCl 2 composites respectively were performed by stirring the solid $(100 \mathrm{mg})$ and $0.5 \mathrm{~mL}$ HMDS $(4 \mathrm{mmol})$ in $10 \mathrm{~mL}$ toluene at $80^{\circ} \mathrm{C}$ in a round bottom flask for $15 \mathrm{~h} .{ }^{38} \mathrm{CES}$ functionalized solid (SBA-CES) was prepared by stirring $100 \mathrm{mg}$ SBA-15 and $0.2 \mathrm{~mL}$ of CES $(1.2 \mathrm{mmol})$ in $10 \mathrm{~mL}$ methanol at room temperature for $15 \mathrm{~h}$. All $\mathrm{CaCl}_{2}$ containing solids were prepared by wet impregnation of solids $(\mathrm{m}=100 \mathrm{mg})$ using 1.5 $\mathrm{mL}$ of $1 \mathrm{M} \mathrm{CaCl}_{2}$ solution in ethanol (leading to a theoretical amount of $62 \mathrm{wt} . \% \mathrm{CaCl}_{2}$ ). The synthesis protocols and designation of the host matrix (SBA-15), pure salt (Ca) and composites $(\mathrm{SCa})$ are summarized in Table 1 . For solids ( $\mathrm{SCa} 2 \& \mathrm{SCa} 4)$ prepared by pre-functionalization, the resulting solids after functionalization were filtered by centrifugation, washed three times with ethanol and dried overnight at $150^{\circ} \mathrm{C}$. For the post- functionalized composite (SCa3), it is likely that $\mathrm{CaCl}_{2}$ leaches out of this composite during washing hence no washing has been performed but dried overnight at $150^{\circ} \mathrm{C}$.

\subsection{Characterization of the solid composites}

X-ray diffractograms were collected in the $5-70^{\circ} 2 \theta$ range with a $0.016^{\circ}$ step using a PANalytical Xpert Pro diffractometer (The Netherlands) equipped with a monochromator, using $\mathrm{Cu} \mathrm{K} \alpha$ radiation (wavelength of $1.54 \AA$ ). Low angle measurements were performed in the same instrument but $2 \theta$ range from $0.75-5^{\circ} .{ }^{13} \mathrm{C}$ CPMAS NMR spectra were obtained at $130.29 \mathrm{MHz}$ on an AVANCE III 500WB spectrometer with a $16.4 \mathrm{~T}$ magnetic field. An excitation pulse of 
$\pi / 2(0.4 \mu \mathrm{s})$ with a scan interval of $1 \mathrm{~s}$ for 4096 scans was employed with adamantane as chemical shift reference. Textural characterizations were realized using nitrogen adsorption/desorption isotherms on a BelsorpMini (Bel Instruments, Japan). Prior to every analysis, samples were outgassed under vacuum $\left(150^{\circ} \mathrm{C}\right.$ for $\left.4 \mathrm{~h}\right)$. The pore size distribution and the mesoporous volume were calculated from the adsorption branch of the isotherms using the Barrett-Joyner-Halenda $(\mathrm{BJH})$ method between $\mathrm{P} / \mathrm{P}_{0}=0.42$ and 0.96 . The total porous volume was measured at $\mathrm{P} / \mathrm{P}_{0}=0.98$ and the surface area were determined by the Brunauer-EmmettTeller (BET) approach. Scanning electron microscopy (SEM) images and elemental mapping of the composites were captured by the Zeiss Merlin Compact (Centre Technologique des Microstructures de l'Université de Lyon) operating at $2 \mathrm{kV}$. Transmission electron microscopy (TEM) was performed on a JEOL $2100 \mathrm{~F}$ field emission instrument operating at $200 \mathrm{kV}$. Infra-

red spectra of the solids were recorded on Safas Monaco IR700 spectrometer. The amount of $\mathrm{CaCl}_{2}$ in the composites was measured using inductively coupled plasma optical emission spectroscopy (ICP-OES) with an ACTIVA spectrometer (Horiba JOBIN YVON). Solids were dissolved in a mixture of $\mathrm{HF}$ and $\mathrm{HNO}_{3}$ prior to ICP-OES analyses. Due to hygroscopic and nonhomogeneous nature of some composites, ICP analyses were performed twice for each composite and the average salt content values are reported herein. A relative standard deviation of around 2 to $4 \%$ was observed in the salt content value of each composite obtained from ICP.

\subsection{Dehydration - Hydration cycles in TGA-DSC}

The water sorption capacity and heat storage performances of all solids were screened in a TGADSC system (Setaram Sensys) coupled with the controlled humidity generator Wetsys capable of supplying the required amount of relative humidity $(\mathrm{RH})$ with a precision of $\pm 0.3 \% \mathrm{RH}$. The humidified carrier gas is pushed into the TGA-DSC through a heated transfer line. In order to 
simultaneously detect both mass and heat flow change, the TGA-DSC is put into vertical operation. Since preliminary investigations (not shown) confirmed that the water sorption kinetics and heat values of the same solid varies with the amount of solid used in a TGA-DSC unit, around $5 \mathrm{mg}$ of solids was used in all the experiments as previously reported. ${ }^{28}$ Dehydration was conducted by allowing the sample to stabilize at $25^{\circ} \mathrm{C}$ for $30 \mathrm{~min}$ before ramping the temperature from $25^{\circ} \mathrm{C}$ to $150^{\circ} \mathrm{C}\left(2^{\circ} \mathrm{C} \cdot \mathrm{min}^{-1}\right)$ in a $20 \mathrm{~mL} \cdot \mathrm{min}^{-1}$ dry air flow (Messer France 5.0, $\left.\mathrm{H}_{2} 0<5 \mathrm{ppm}\right)$. The sample was kept at $150^{\circ} \mathrm{C}$ for $3 \mathrm{~h}$ before cooling down to $25^{\circ} \mathrm{C}\left(5^{\circ} \mathrm{C} \cdot \mathrm{min}^{-1}\right)$. The hydration step was then performed at $25^{\circ} \mathrm{C}$ in the air flow $\left(20 \mathrm{~mL} \cdot \mathrm{min}^{-1}\right)$ containing $30 \%$ of $\mathrm{RH}$ for a duration of $16 \mathrm{~h}$. The first dehydration-hydration cycle is followed by a second (or more) cycle(s) to study the reversibility and stability of water sorption and heat storage capacities of the solids. The relative standard deviation in the dehydration/hydration enthalpy value of the composites is around $\pm 15 \mathrm{~kJ} \cdot \mathrm{kg}^{-1}$ solid.

\section{Results and discussion}

\subsection{Characterization of $\mathrm{SBA}-15 / \mathrm{CaCl}_{2}$ composites}

Figure 1a shows low angle XRD of SBA-15 and SCa composites. The low angle XRD pattern of SBA-15, exhibits three peaks at $2 \theta=0.95^{\circ}, 1.6^{\circ}$ and $1.8^{\circ}$ associated with highly ordered mesoporous SBA-15 with a p6mm hexagonal symmetry. ${ }^{39}$ After incorporation of the salt, the diffraction patterns of all composites differ from that of SBA-15 irrespective of the functionalization. While non-functionalized SCal did not exhibit any XRD peaks, one broad peak was observed at around $2 \theta=0.95^{\circ}$ for functionalized composites ( $\mathrm{SCa} 2, \mathrm{SCa} 3$ and $\left.\mathrm{SCa} 4\right)$ (Fig. 1a). This suggests that large portion of the ordered mesopores in non-functionalized SCa1 is filled by the salt or salt hydrates. ${ }^{31} \mathrm{~A}$ broad peak is observed in functionalized SCa composites 
(Fig. 1a) possibly due to the presence of some void mesopores since a small portion of the salt may remain outside the functionalized silica pores as a separate phase. Another possibility is that the electronic contrast observed in the composite is higher for the functionalized silica having a lower electronic density.
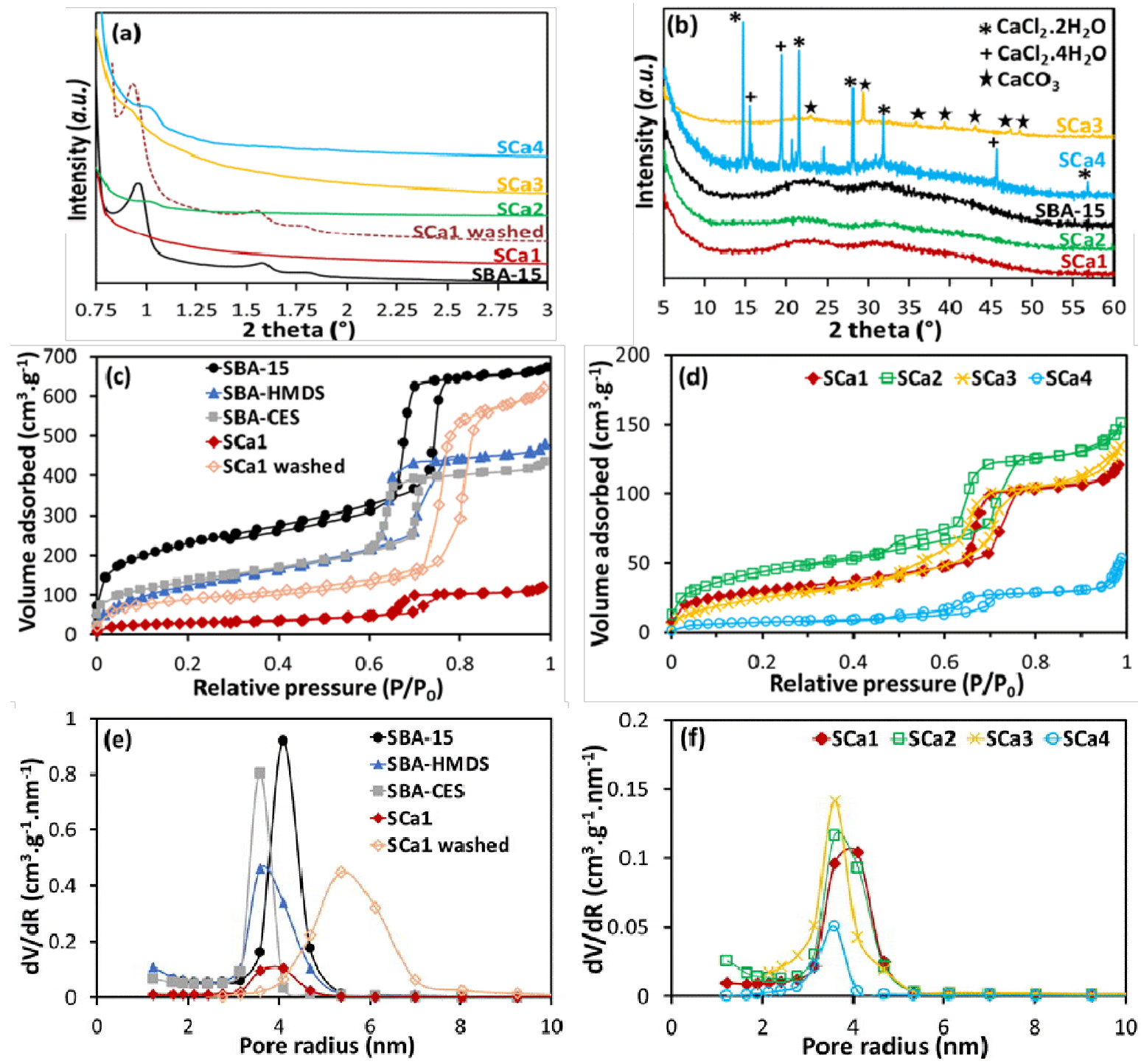

Figure 1. (a) Low angle and (b) wide angle X-ray diffractograms, (c,d) $\mathrm{N}_{2}$ adsorption/desorption isotherms and (e,f) pore size distribution curves of SBA-15, functionalized SBA-15 (SBAHMDS and SBA-CES) and SCa composites 
In order to verify if $\mathrm{CaCl}_{2}$ addition resulted in some evolution of the ordered pore structure in SBA-15, low angle XRD was also performed after the removal of $\mathrm{CaCl}_{2}$ salt in $\mathrm{SCa}$ by washing. All three XRD peaks (of SBA-15) re-appeared after washing off the salt from SCa1 composite but with a low-angle shift. It confirms the fact that the ordered mesopore structure of the composite remains globally stable after addition of large amount ( $\sim 60 \mathrm{wt} . \%)$ of $\mathrm{CaCl}_{2}$ but a partial modification of the silica meso-structure is observed possibly due to the swelling effect of the silica induced by the added salt. The decreased intensity in the XRD peaks of the composites is due to the salt particles that fill the SBA-15 mesopores.

Wide angle X-ray diffractograms of SCa1 and SCa2 composites showed only broad peaks of SBA-15 and no $\mathrm{CaCl}_{2}$ phases were evident. It indicates that the salt is either amorphous or liquid in non-functionalized and HMDS-functionalized silica supports (Fig. 1b). ${ }^{27}$ Though, $\mathrm{CaCl}_{2}$ phases were not present in the XRD of SCa3, peaks associated with $\mathrm{CaCO}_{3}$ were observed (Fig. 1b). This suggests that during the post functionalization using HMDS and toluene at $80^{\circ} \mathrm{C}$, some $\mathrm{CaCl}_{2}$ phases already present in the SBA-15 might have transformed to $\mathrm{CaCO}_{3}$ via carbonation route. ${ }^{40}$ XRD of $\mathrm{COO}^{-}$functionalized $\mathrm{SCa} 4$ exhibited both $\mathrm{CaCl}_{2} \cdot 2 \mathrm{H}_{2} \mathrm{O}$ and $\mathrm{CaCl}_{2} \cdot 4 \mathrm{H}_{2} \mathrm{O}$ phases suggesting the presence of large crystalline $\mathrm{CaCl}_{2}$ particles in this composite that are outside the silica mesopores (Fig. 1b).

Infrared spectroscopy was performed to confirm the incorporation of the functional groups into the SBA-15 matrix (Fig. S1). A broad vibrational band at $\sim 1100 \mathrm{~cm}^{-1}$ in pure SBA-15 is due to the stretching of Si-O-Si groups. Functionalization with methyl groups in SBA-HMDS (Fig. S1a), $\mathrm{SCa} 2$ and $\mathrm{SCa} 3$ solids (Fig. S1b) is confirmed by the appearance of the $\mathrm{Si}_{-} \mathrm{CH}_{3}$ bending vibration at $1260 \mathrm{~cm}^{-1} \cdot{ }^{38,41}$ This is accompanied by a decrease in the intensity of $v \mathrm{Si}-\mathrm{OH}$ band at around $945 \mathrm{~cm}^{-1}$ and appearance of a Si-C rocking vibration band at $845 \mathrm{~cm}^{-1} \cdot{ }^{41}$ In addition, post- 
functionalized $\mathrm{SCa} 3$ composite exhibits an intense band at $1409 \mathrm{~cm}^{-1}$ due to the asymmetric $v_{3}$ vibration of $\mathrm{CO}_{3}$ in $\mathrm{CaCO}_{3}$ present in this composite which is in good agreement with the XRD result (Fig. S1b). ${ }^{42,43} \mathrm{COO}^{-}$symmetric and asymmetric stretching bands at 1415 and $1570 \mathrm{~cm}^{-1}$ respectively, confirmed the presence of carboxyl group in the SBA-CES sample (Fig. S1a). ${ }^{44,45}$ In case of SCa4, the intensity of these carboxylic stretching bands decreased considerably and a new peak appeared at $1552 \mathrm{~cm}^{-1}$ suggesting the coordination of $\mathrm{COO}^{-}$groups to $\mathrm{Ca}^{2+}$ in the bidentate mode (Fig. S1b) ${ }^{46,47}$ Aiming to confirm the interaction of the $\mathrm{COO}^{-}$group to $\mathrm{Ca}^{2+}$, we further performed ${ }^{13} \mathrm{C}$ MAS NMR of SBA-CES and SCa4. The ${ }^{13} \mathrm{C}$ MAS NMR peak of $\mathrm{COO}^{-}$ exhibited a downfield shift (186 ppm) compared to that of SBA-CES (182 ppm) confirming the coordination between $\mathrm{COO}^{-}$groups and $\mathrm{Ca}^{2+}$ ions in $\mathrm{SCa} 4$ (Fig. S2). ${ }^{48,49}$ 


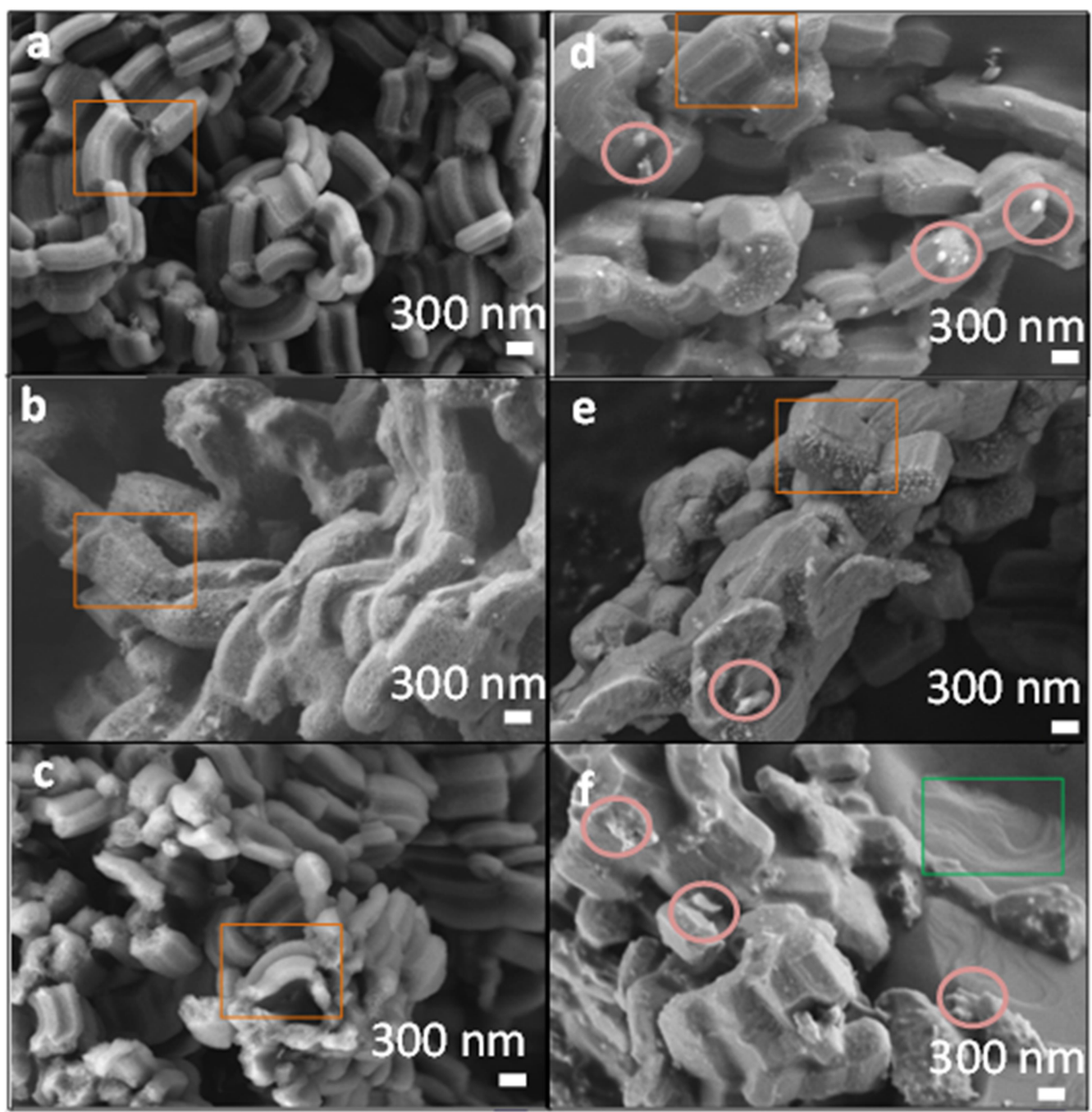

Figure 2. SEM images of (a) SBA-15, (b) SCa1, (c) SCa1 washed, (d) SCa2, (e) SCa3 and (f) $\mathrm{SCa} 4$ composites

SEM image of SBA-15 showed the presence of hexagonal shaped particles whose size ranges around $600 \times 300 \mathrm{~nm}$ (Fig. 2a). SEM of the non-functionalized composite SCa1 revealed that the silica seems to be gorged like a sponge with the $\mathrm{CaCl}_{2}$ particles (Fig. 2b). The particle size has increased after the salt introduction as shown inside the orange squares. However, the morphology of the SBA-15 is regained after washing the salt away from SCa1 (Fig. 2c) which is in good agreement with the XRD results. This observation indicates that mesoporous silicas are very flexible matrices, capable of swelling under the effect of salt without breaking. SCa2 and SCa3 also exhibited similar morphology as SCa1, i.e., silica particles appear swelled with the salt 
(orange square) (Figs. $2 \mathrm{~d} \& 2 \mathrm{e}$ ). Some $\mathrm{CaCl}_{2}$ white particles with size of $\sim 50 \mathrm{~nm}$ are also observed on the surface (pink circles) (Figs. 2d-2f). The $\mathrm{COO}^{-}$functionalized SCa4 image showed that the salt seems to cover the silica particles with some zones (green square in Fig. 2f) containing the salt alone. It confirms the non-homogeneous nature of this composite which is in good agreement with XRD results. This SEM observation also indicates the possible accumulation of $\mathrm{CaCl}_{2}$ particles at the silica surface of $\mathrm{SCa} 4$. Elemental mapping images confirmed that the $\mathrm{CaCl}_{2}$ salt is homogeneously distributed in $\mathrm{SCa} 1$ solid with a calcium/silicon atomic ratio measured around 0.68 (Fig. S3).

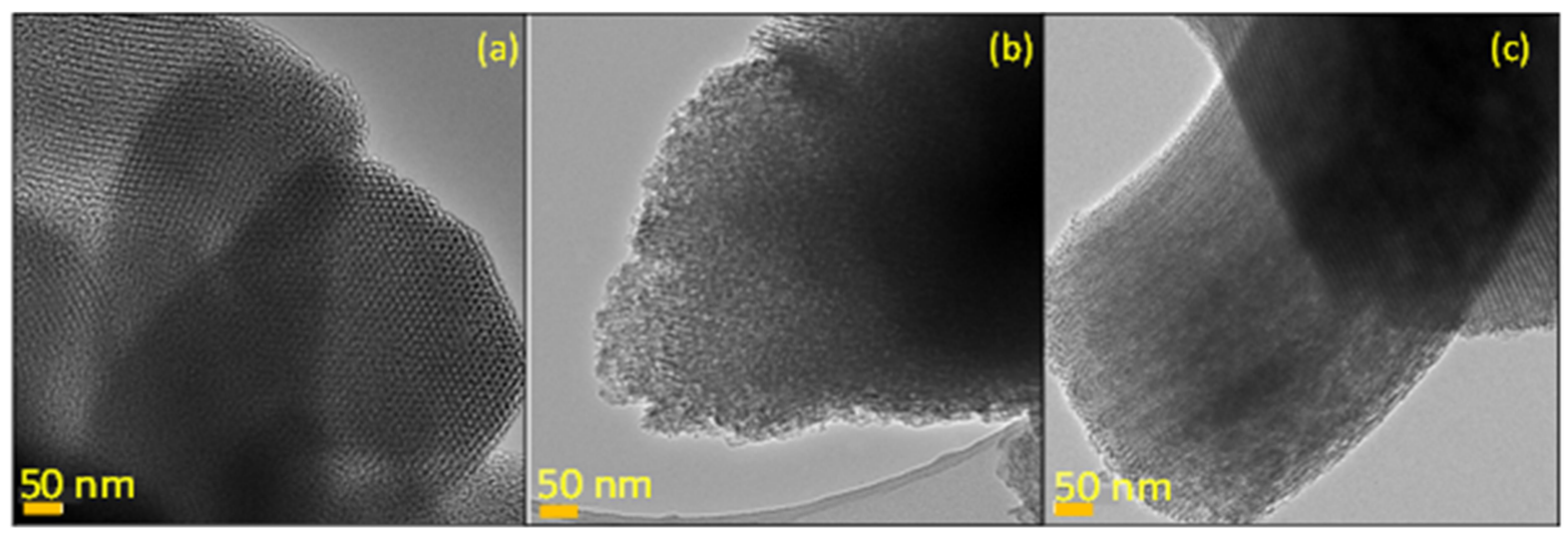

Figure 3. TEM images (a) SBA-15, (b) SCa1, (c) SCa2 composites

The TEM image of the SBA-15 showed organized mesoporous texture with the presence of $\sim 7$ nm channels (Fig. 3a). The meso-structure of the parent silica is still observed but with a lower contrast in the composites SCa1 and SCa2 (Fig. $3 b$ \& 3c). The images also demonstrated a partial loss of the meso-structure organization, in agreement with the observations of Ristic et $a l^{32}$

Nitrogen adsorption isotherm of the SBA-15 confirms the presence of micropores along with mesopores (Fig. 1c). Both HMDS and CES functionalization decreased the surface area of SBA$15\left(828 \mathrm{~m}^{2} \cdot \mathrm{g}^{-1}\right)$ to $490 \mathrm{~m}^{2} \cdot \mathrm{g}^{-1}$ and $482 \mathrm{~m}^{2} \cdot \mathrm{g}^{-1}$ respectively (Table $2 \&$ Fig. 1c). However, the 
functionalized solids (SBA-HMDS \& SBA-CES) retained around $70-80 \%$ of the mesoporous volume suggesting the fact that they have sufficient mesoporous volume to accommodate $\mathrm{CaCl}_{2}$ salt (Table 2 and Fig. 1c). After the impregnation of $\mathrm{CaCl}_{2}$, the BET surface area decreased from $828 \mathrm{~m}^{2} \cdot \mathrm{g}^{-1}$ in non-functionalized SBA-15 to $105 \mathrm{~m}^{2} \cdot \mathrm{g}^{-1}$ in SCa1 composite (Fig. 1). Similarly, methyl-functionalized and $\mathrm{CaCl}_{2}$ impregnated composites $\mathrm{SCa} 2$ and $\mathrm{SCa} 3$ also showed lower surface areas of $155 \mathrm{~m}^{2} \cdot \mathrm{g}^{-1}$ and $100 \mathrm{~m}^{2} \cdot \mathrm{g}^{-1}$ respectively (Fig. 1d). Impregnation of the salt resulted in $\sim 70$ to $80 \%$ decrease in mesoporous volume and a loss of the silica microporosity (Table 2). Hence, considerable reduction in the mesoporous volume of SCa1, SCa2 and SCa3 composites suggests the capacity of their corresponding host matrix mesopores to accommodate large amount of $\mathrm{CaCl}_{2}$ particles. Around 20 to $30 \%$ of unfilled mesoporous volume that are still available in these composites may facilitate the diffusion of water molecules through the mesopores during hydration/dehydration cycles. ${ }^{10}$ The average pore size of all solids remained almost steady at $\sim 7$ to $8 \mathrm{~nm}$ irrespective of functionalization and $\mathrm{CaCl}_{2}$ impregnation (Figs. 1e-f $\&$ Table 2). For $\mathrm{COO}^{-}$functionalized $\mathrm{SCa} 4$ composite, the impregnation of $\mathrm{CaCl}_{2}$ resulted in a drastic decrease in the BET surface area $\left(482 \mathrm{~m}^{2} \cdot \mathrm{g}^{-1}\right)$ and mesoporous volume $\left(0.55 \mathrm{~cm}^{3} \cdot \mathrm{g}^{-1}\right)$ of the parent solid (SBA-CES) to $27 \mathrm{~m}^{2} \cdot \mathrm{g}^{-1}$ and $0.05 \mathrm{~cm}^{3} \cdot \mathrm{g}^{-1}$ respectively, leading to a non-porous composite. After the removal of $\mathrm{CaCl}_{2}$ salt in $\mathrm{SCa} 1$ by washing, only partial restoration of the silica texture was observed (Fig. 1c \& Table 2) and the microporosity is less important compared to the initial sample. While the mesoporous volume is completely restored with a small increment $\left(0.93 \mathrm{~cm}^{3} \cdot \mathrm{g}^{-1}\right)$, the pore size is increased to $10.7 \mathrm{~nm}$ after washing (Fig. 1e). These observations reveal that mesopores have been swelled by the salt filling-and the microporosity of the silica walls has been compressed. 
Table 2. ICP and $\mathrm{N}_{2}$ adsorption/desorption isotherms results

\begin{tabular}{|c|c|c|c|c|c|c|}
\hline Solids & $\begin{array}{c}\mathrm{CaCl}_{2} \\
(\text { wt. \%) }\end{array}$ & $\begin{array}{c}\text { BET SA } \\
\left(\mathrm{m}^{2} \cdot \mathrm{g}^{-1}\right)\end{array}$ & $\begin{array}{c}V_{\text {porous }} \\
\left(\mathrm{cm}^{3} \cdot \mathrm{g}^{-1}\right)\end{array}$ & $\begin{array}{l}V_{\text {meso ads }} \\
\left(\mathrm{cm}^{3} \cdot \mathrm{g}^{-1}\right)\end{array}$ & $\begin{array}{c}\text { Max pore } \\
\text { diameter } \\
(\mathrm{nm})\end{array}$ & $\begin{array}{c}\% \\
\text { mesopores }^{\text {filled }} \\
\end{array}$ \\
\hline SBA-15 & - & 828 & 1.00 & 0.81 & 8.2 & - \\
\hline SBA-HMDS & - & 490 & 0.74 & 0.63 & 7.2 & - \\
\hline SBA-CES & - & 482 & 0.61 & 0.55 & 7.2 & - \\
\hline SCa1 & 59.8 & 105 & 0.18 & 0.16 & 8.0 & 80 \\
\hline $\begin{array}{l}\text { SCa1 } \\
\text { whashed }\end{array}$ & - & 322 & 0.96 & 0.93 & 10.7 & \\
\hline SCa2 & 59.2 & 155 & 0.23 & 0.18 & 7.0 & 77 \\
\hline SCa3 & 54.9 & 100 & 0.20 & 0.19 & 7.0 & 76 \\
\hline SCa4 & 52.3 & 27 & 0.08 & 0.05 & 7.0 & 94 \\
\hline
\end{tabular}

*wt.\% determined by ICP-OES based on anhydrous $\mathrm{CaCl}_{2}$

${ }^{a}$ Difference between the mesoporous volumes of the composites before and after $\mathrm{CaCl}_{2}$ impregnation

N.B. $\mathrm{V}_{\text {porous }}=$ total pore volume; $\mathrm{V}_{\text {meso ads }}=$ Mesoporous volume determined from adsorption branch with BJH method.

As a partial conclusion to this section, the successful incorporation of the $\mathrm{CH}_{3}-$ and $\mathrm{COO}^{-}$groups in the silica matrix was confirmed by FTIR. Homogeneous composites containing $60 \mathrm{wt} \%$ of calcium chloride in mesoporous silica (non-functionalized SCa1 or methyl functionalized SCa2 and $\mathrm{SCa} 3$ ) have been obtained. A drastic decrease in the mesoporous volume as well as the loss in the microporosity of support matrix in the composites was observed after the incorporation of $\mathrm{CaCl}_{2}$. SEM results showed that the mesoporous silica behaves like a sponge for salt, as $80 \%$ of its mesoporous volume has been filled with salt. Accumulation of large $\mathrm{CaCl}_{2}$ particles was clearly observed at the surface of CES functionalized composite (SCa4) explaining the complete loss of porosity in this composite.

\subsection{Tests for water sorption and heat storage capacities in TG-DSC}

\subsubsection{Dehydration/hydration behaviour of the solids}



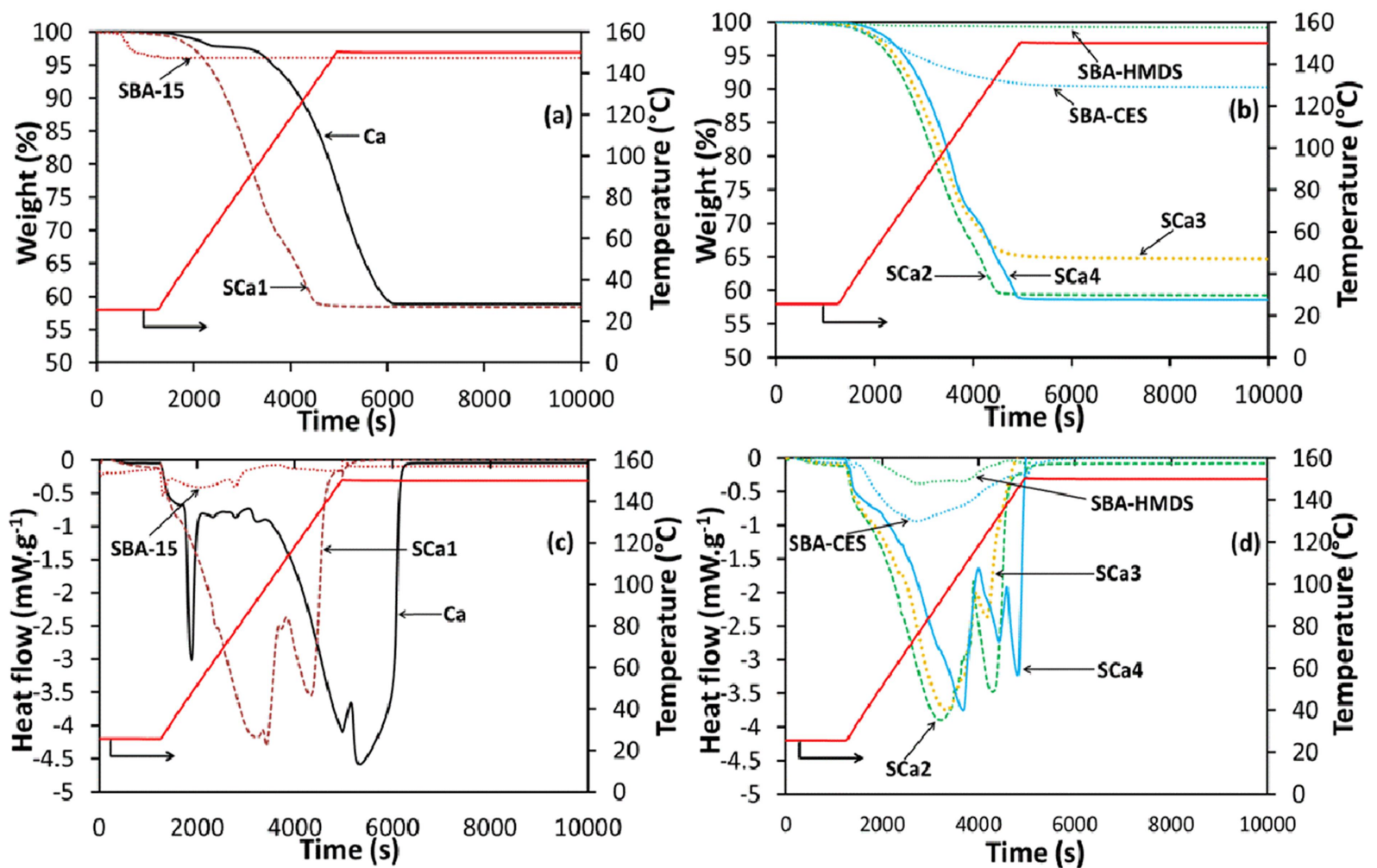

Figure 4. TGA curves of (a) non-functionalized solids and $\mathrm{CaCl}_{2} \cdot \mathrm{nH}_{2} \mathrm{O}$ and (b) functionalized solids, during the second dehydration cycle and respective DSC curves of (c) non-functionalized solids and $\mathrm{CaCl}_{2} \cdot \mathrm{nH}_{2} \mathrm{O}$ and (d) functionalized solids

The dehydration tests (cycle 2) performed with host matrices SBA-15, SBA-HMDS and SBA-CES exhibited around 4, 1 and 9 wt.\% weight loss respectively (Figs. 4a \& 4b). The weight change is more pronounced for carboxylic functionalized SBA-CES followed by nonfunctionalized SBA-15 and hydrophobic functionalized SBA-HMDS which demonstrates the possible influence of functionalization on the water sorption and the heat storage capacity of host solids (Fig. 4). Hence, the extent of $\mathrm{CaCl}_{2}$ hydration in the $\mathrm{SCa}$ composites was calculated from the mass of the dried sample (final weight loss plateau obtained at the end of a dehydration step) after subtracting the weight loss of mere host solids. The maximum extent of hydration and different $\mathrm{CaCl}_{2}$ forms determined from the weight changes in TGA during the second dehydration cycle are given in Table 3. 
Table 3. Transformation stages of $\mathrm{CaCl}_{2} \cdot \mathrm{nH}_{2} \mathrm{O}$ during second dehydration cycle of solids

\begin{tabular}{|c|c|}
\hline Solids & Dehydration cycle 2 \\
\hline $\mathrm{Ca}$ & $\mathrm{CaCl}_{2} \cdot 4 \cdot 3 \mathrm{H}_{2} \mathrm{O} \rightarrow \mathrm{CaCl}_{2}+4.3 \mathrm{H}_{2} \mathrm{O}$ \\
\hline SCa1 & $\begin{array}{c}\mathrm{CaCl}_{2} \cdot 6 \cdot 3 \mathrm{H}_{2} \mathrm{O} \rightarrow \mathrm{CaCl}_{2} \cdot 1 \cdot 8 \mathrm{H}_{2} \mathrm{O}+4 \cdot 5 \mathrm{H}_{2} \mathrm{O} \\
\mathrm{CaCl}_{2} \cdot 1 \cdot 8 \mathrm{H}_{2} \mathrm{O} \rightarrow \mathrm{CaCl}_{2}+1.8 \mathrm{H}_{2} \mathrm{O}\end{array}$ \\
\hline SCa2 & $\begin{array}{c}\mathrm{CaCl}_{2} \cdot 6 \cdot 8 \mathrm{H}_{2} \mathrm{O} \rightarrow \mathrm{CaCl}_{2} \cdot 1 \cdot 9 \mathrm{H}_{2} \mathrm{O}+4 \cdot 9 \mathrm{H}_{2} \mathrm{O} \\
\mathrm{CaCl}_{2} \cdot 1 \cdot 9 \mathrm{H}_{2} \mathrm{O} \rightarrow \mathrm{CaCl}_{2}+1 \cdot 9 \mathrm{H}_{2} \mathrm{O}\end{array}$ \\
\hline SCa3 & $\begin{array}{c}\mathrm{CaCl}_{2} \cdot 6 \cdot 2 \mathrm{H}_{2} \mathrm{O} \rightarrow \mathrm{CaCl}_{2} \cdot 1 \cdot 8 \mathrm{H}_{2} \mathrm{O}+4 \cdot 4 \mathrm{H}_{2} \mathrm{O} \\
\mathrm{CaCl}_{2} \cdot 1 \cdot 8 \mathrm{H}_{2} \mathrm{O} \rightarrow \mathrm{CaCl}_{2}+1.8 \mathrm{H}_{2} \mathrm{O}\end{array}$ \\
\hline SCa4 & $\begin{array}{c}\mathrm{CaCl}_{2} \cdot 6 \cdot 4 \mathrm{H}_{2} \mathrm{O} \rightarrow \mathrm{CaCl}_{2} \cdot 2 \cdot 2 \mathrm{H}_{2} \mathrm{O}+4 \cdot 2 \mathrm{H}_{2} \mathrm{O} \\
\mathrm{CaCl}_{2} \cdot 2 \cdot 2 \mathrm{H}_{2} \mathrm{O} \rightarrow \mathrm{CaCl}_{2} \cdot 0.9 \mathrm{H}_{2} \mathrm{O}+1 \cdot 3 \mathrm{H}_{2} \mathrm{O} \\
\mathrm{CaCl}_{2} \cdot 0.9 \mathrm{H}_{2} \mathrm{O} \rightarrow \mathrm{CaCl}_{2}+0.9 \mathrm{H}_{2} \mathrm{O}\end{array}$ \\
\hline
\end{tabular}

No hydration cycle was performed before dehydration cycle 1.

First hydration cycle is performed at $25^{\circ} \mathrm{C}$ and $\mathrm{RH}=30 \%$ between the dehydration steps $1 \& 2$.

As mentioned above, the $\mathrm{CaCl}_{2} \cdot \mathrm{nH}_{2} \mathrm{O}$ generally exists in three stable hydrated forms $(\mathrm{n}=2,4 \&$ 6) and $\mathrm{CaCl}_{2} \cdot 6 \mathrm{H}_{2} \mathrm{O}$ form is the most hydrated form among all. Hence, different solids may possess different $\mathrm{CaCl}_{2}$ forms at the beginning of the first dehydration cycle (condition step) that make it is difficult to compare the hygroscopic nature of composites before first cycle as aforementioned. However, the weight loss curves of the solids during the first dehydration step clearly suggest that all composites, except $\mathrm{SCa} 4$, are more hygroscopic than commercial $\mathrm{CaCl}_{2} \cdot 2 \mathrm{H}_{2} \mathrm{O}$ (Fig. S4). This increased hygroscopic nature of the composites is possibly due to the presence of well dispersed salt particles in the silica pores that are capable of adsorbing more humidity than commercial $\mathrm{CaCl}_{2} \cdot 2 \mathrm{H}_{2} \mathrm{O}$ salt.

Before performing the second (or more) dehydration cycle(s), all composites were treated uniformly at same conditions and hence the results are reliable and comparable. Also, it is worth to note that the amount of adsorbed water (the value of ' $\mathrm{n}$ ' in $\mathrm{CaCl}_{2} \cdot \mathrm{nH}_{2} \mathrm{O}$ ) calculated for the hydrated $\mathrm{CaCl}_{2}$ forms in the composites were not a whole number (e.g., $\left.\mathrm{n}=0.9,1.8,4.4,6.2 \ldots\right)$ 
and varied slightly compared to the generally known stable $\mathrm{CaCl}_{2}$ forms $(\mathrm{n}=1,2,4 \& 6)$. These fractional values are due to the small errors in the amount of salt determined using ICP and/or due to presence of mixture of salt hydrates in composites that exhibited overlapping TGA steps (or DSC curves). In addition, the ' $\mathrm{n}$ ' values can be also higher than the most saturated $\mathrm{CaCl}_{2} \cdot 6 \mathrm{H}_{2} \mathrm{O}$ form if the salt exists in solution inside TGA crucible by uptaking water molecules even after attaining the $\mathrm{CaCl}_{2} \cdot 6 \mathrm{H}_{2} \mathrm{O}$ form. ${ }^{28}$ The initial weight at the beginning of the second dehydration cycle in Fig. 4 corresponds also to the maximum weight attained after $16 \mathrm{~h}$ of first hydration cycle. Before starting the second dehydration cycle, the salt exists rather in the form of most hydrated $\mathrm{CaCl}_{2} \cdot 6 \mathrm{H}_{2} \mathrm{O}$ phase in all composites (Table 3 ). The composites, especially $\mathrm{SCa} 2$, possessed slightly higher amount of water than that possessed by the most hydrated $\mathrm{CaCl}_{2} \cdot 6 \mathrm{H}_{2} \mathrm{O}$ form. The mere salt exists as rather $\mathrm{CaCl}_{2} \cdot 4 \cdot 0 \mathrm{H}_{2} \mathrm{O}$ phase that is formed by hydration of pure $\mathrm{CaCl}_{2} \cdot 2 \mathrm{H}_{2} \mathrm{O}$ salt during the first hydration cycle (Table 3). Hence, all the composites attained the most hydrated $\mathrm{CaCl}_{2} \cdot 6 \mathrm{H}_{2} \mathrm{O}$ form inside the TGA crucible at the end of all hydration cycles using the conditions employed (16 h and 30\%RH) in this study.

During dehydration cycle 2, all composites, irrespective of their initial amount of water molecules, exhibited a change of slope in the TGA curves at around $115^{\circ} \mathrm{C}(\sim 3800 \mathrm{~s})$ (Fig. 4). Two endothermic peaks were observed for all composites except SCa4 depicting that the first stage of dehydration (probably $\mathrm{CaCl}_{2} \cdot 6 \mathrm{H}_{2} \mathrm{O} \rightarrow \mathrm{CaCl}_{2} \cdot 2 \mathrm{H}_{2} \mathrm{O}$ ) occurs from $\sim 25^{\circ} \mathrm{C}$ to $\sim 65^{\circ} \mathrm{C}$ and the second dehydration step (probably $\mathrm{CaCl}_{2} \cdot 2 \mathrm{H}_{2} \mathrm{O} \rightarrow \mathrm{CaCl}_{2}$ ) takes place from about $65^{\circ} \mathrm{C}$ to $\sim 143^{\circ} \mathrm{C}$ (Fig. $4 \mathrm{c} \& 4 \mathrm{~d}$ ). The formation of such intermediate $\mathrm{CaCl}_{2}$ phases is in good agreement with previous studies. ${ }^{11,50,51}$ For SCa4, a peak appeared between 135 and $150^{\circ} \mathrm{C}$ in addition to the two aforementioned endothermic peaks (Table 3). While the complete dehydration of all composites occurred even before reaching the maximum temperature $\left(150^{\circ} \mathrm{C}\right)$, the dehydration of 
commercial $\mathrm{CaCl}_{2} \cdot 2 \mathrm{H}_{2} \mathrm{O}$ was completed only after $15 \mathrm{~min}$ (isothermal step) at $150^{\circ} \mathrm{C}$ (Figs. 4). The maxima of the DSC peaks shifted considerably from $\sim 150^{\circ} \mathrm{C}$ in pure $\mathrm{CaCl}_{2} \cdot 2 \mathrm{H}_{2} \mathrm{O}$ to around $85-120^{\circ} \mathrm{C}$ in composites $\left(\sim 100-140^{\circ} \mathrm{C}\right.$ for SCa4) indicating that the impregnation of salt on silica support facilitates the dehydration process (Fig. 4). This shift in the dehydration peaks and the increased rate of dehydration in composites compared to pure salt is possibly due to the well dispersed $\mathrm{CaCl}_{2}$ salt particles in the composite mesopores. A sharp endothermic peak in the DSC curve of pure $\mathrm{CaCl}_{2}$ salt at $35^{\circ} \mathrm{C}$ is due to the melting point of very small amount of any $\mathrm{CaCl}_{2} \cdot 6 \mathrm{H}_{2} \mathrm{O}$ phases that are formed during previous hydration cycle. ${ }^{21}$
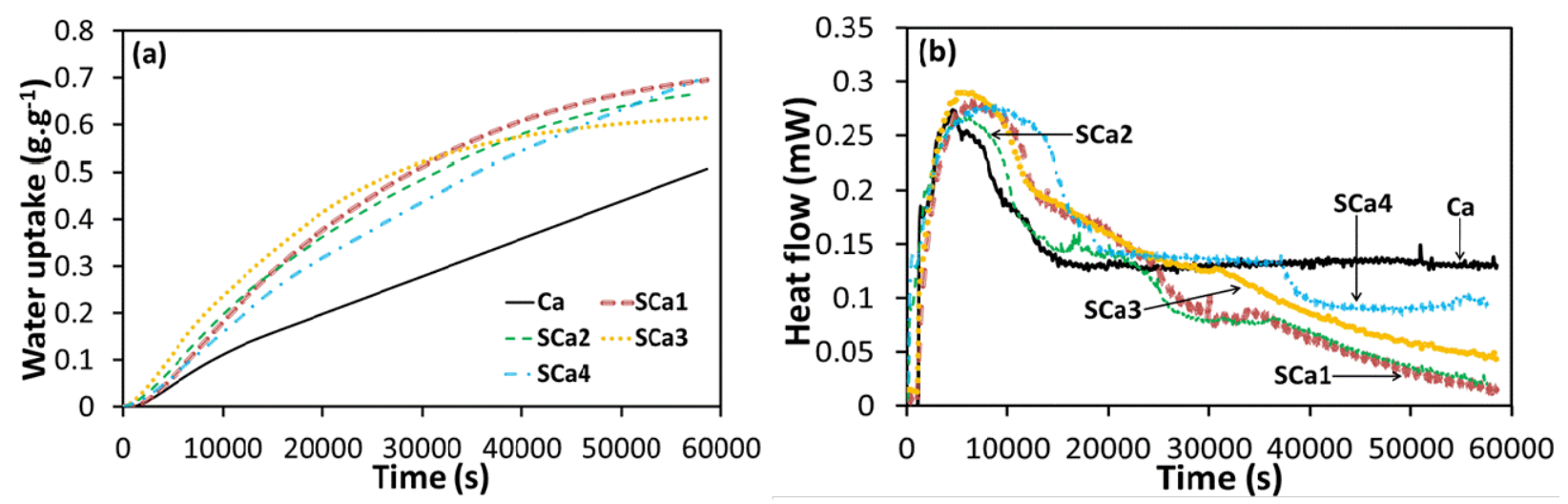

Figure 5. (a) TGA and (b) DSC curves of dehydrated solids during second hydration cycle at $25^{\circ} \mathrm{C}, 30 \% \mathrm{RH}$ and $1 \mathrm{~atm}$

Figure 5 shows TGA and DSC curves of all composites during the second hydration cycle at $25^{\circ} \mathrm{C}$ and $30 \% \mathrm{RH}$. Initial weight (expressed as water uptake per gram of dried solid) at the beginning of second hydration cycle corresponds to the dried sample obtained from the second dehydration cycle (Fig. 5a). All composites in their dehydrated form adsorbs water during $16 \mathrm{~h}$ of second hydration cycle and their weight (except pure salt) increases to a maximum of around 0.7 g. $\mathrm{g}^{-1}$ i.e., the weight corresponds to maximum weight of hydrated solids obtained in the previous (first) hydration cycle (Fig. 5a). However, commercial $\mathrm{CaCl}_{2}$ salt could only attain a maximum of $0.5 \mathrm{~g} \cdot \mathrm{g}^{-1}$ during second hydration cycle which is lower than the maximum weight 
$\left(0.7\right.$ g. $\left.\mathrm{g}^{-1}\right)$ attained during first hydration cycle. Hence, for hydration cycles performed for $16 \mathrm{~h}$ at $30 \% \mathrm{RH}$, the water sorption capacity of all composites exhibited a reversible behaviour while the pure $\mathrm{CaCl}_{2}$ salt lost its reversibility. The above results suggest that the water sorption performance of the $\mathrm{CaCl}_{2}$ salt has improved after it is incorporated into a porous SBA-15 matrix. Also, the weight gain of all solids did not reach the saturation depicting the fact that these solids need more than $16 \mathrm{~h}$ to reach the equilibrium sorption under the hydration conditions employed in this study (Fig. 5a). This is more evident from the DSC curves of all solids, in which the heat of water sorption did not return completely to the initial base line $(\mathrm{t}=0)$ even after $16 \mathrm{~h}$ of hydration suggesting that the equilibrium sorption is not attained for these solids (Fig. 5b). For SCa4 and pure $\mathrm{CaCl}_{2}$ salt, the heat of sorption decreases to a certain value after attaining a maximum and remained at this value until the end of hydration $(16 \mathrm{~h})$ without returning to the initial baseline. This result indicates the possibility of slow rate of water uptake in SCa4 and pure salt compared to other composites which will be discussed below in the sorption kinetics section.

\subsubsection{Heat storage capacities of the solids}

Heat storage capacities of the solids during the dehydration and hydration cycles were calculated by performing integration of the DSC curves (Fig. S5). Though the values of enthalpy of hydration per $\mathrm{kg}$ of solids varied considerably among the composites, it is difficult to perform a comparison study as the amount of salt per kg of composites vary and hence their corresponding enthalpy values. Therefore, performance of the composites will be compared using the enthalpy values per mol of anhydrous $\mathrm{CaCl}_{2}$ that take into account the exact amount of $\mathrm{CaCl}_{2}$ in each solid (Table 4, Fig. S6a). The heat storage density per unit volume was determined for the better performing SCa1 composite with an apparent density of $0.42 \mathrm{~g} . \mathrm{cm}^{-3}$ and hydration enthalpy of $1711 \mathrm{~kJ} . \mathrm{kg}^{-1}$. The estimated heat storage density of SCa1 is 0.72 GJ.m ${ }^{-3}$ (bed composite energy 
density of $200 \mathrm{kWh} . \mathrm{m}^{-3}$; minimum being $150 \mathrm{kWh} . \mathrm{m}^{-3}$ required for the application ${ }^{8}$, which seems to be a classical value considering the reported values of salts ( $\sim 1$ to 3 GJ.m ${ }^{-3}$ ) and composites (usually below 1 GJ.m ${ }^{-3}$ ). ${ }^{13-16,27}$

Table 4. Enthalpies of dehydration/hydration of pure salt and composites

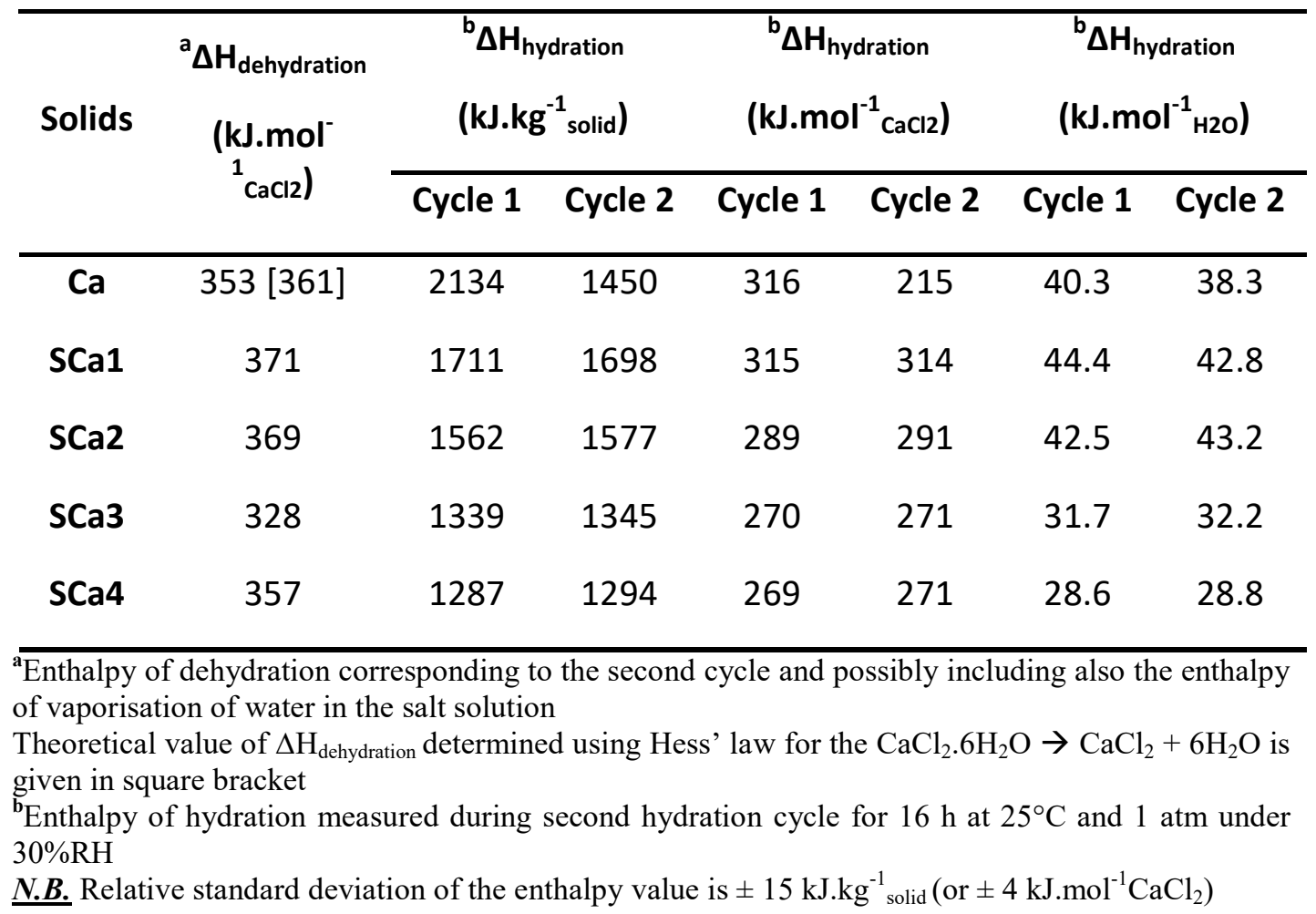

Table 4 and Figure S6b show enthalpy of hydration per mole of $\mathrm{CaCl}_{2}$ during the two successive hydration cycles for all solids. $\Delta \mathrm{H}_{\text {hydration }}$ of the composites remained rather steady during both hydration cycles depicting the fact that heat storage capacities of all composites are reversible like their water sorption behaviour. For commercial $\mathrm{CaCl}_{2}$ salt, the $\Delta \mathrm{H}_{\text {hydration }}$ decreased

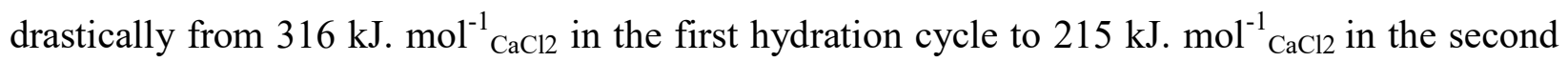
hydration cycle indicating that the heat storage capacity of pure salt is not reversible due to slower hydration rate at the hydration conditions employed in this study (Table 4 \& Fig. S6b). 
The enthalpies of hydration per mol of $\mathrm{CaCl}_{2}$ and hence the heat storage capacities of the composites follow the order: $\mathrm{SCa} 1>\mathrm{SCa} 2>\mathrm{SCa} 3 \sim \mathrm{SCa} 4$. Whereas, the heat released by composites per mol of $\mathrm{H}_{2} \mathrm{O}$ adsorbed during the hydration period follows the order: SCa1 $\mathrm{SCa} 2>\mathrm{SCa} 3>\mathrm{SCa} 4$ (Table 4). The non-functionalized SCa1 composite exhibited higher heat storage capacity compared to $-\mathrm{CH}_{3}$ and $\mathrm{COO}$ - functionalized composites.

\subsubsection{Hydration kinetics of the solids}

Aiming to study the water sorption kinetics (rate of $\mathrm{CaCl}_{2}$ hydration) of the composites during the second hydration cycle, water uptake by the composites is determined by calculating the ratio of number of moles of water adsorbed $\left(\mathrm{n}_{\mathrm{H} 2 \mathrm{O}}\right)$ per mol of anhydrous $\mathrm{CaCl}_{2}\left(\mathrm{n}_{\mathrm{CaCl}}\right)$ as reported in Fig. 6. Water uptake is not observed until around $2500 \mathrm{~s}$ because this time period corresponds to a stabilization phase employed at $25^{\circ} \mathrm{C}$ before switching the relative humidity from 0 to $30 \%$. Though the qualitative trend in the adsorption curves of all composites seem similar for both the normalized ratio $\left(\mathrm{n}_{\mathrm{H} 2 \mathrm{O}} / \mathrm{n}_{\mathrm{CaCl} 2}\right)$ and the absolute weight curves, the quantitative comparison between the kinetic behaviours (rate of $\mathrm{CaCl}_{2}$ hydration) of the solids is precise using normalized ratio curves (Fig. 5a \& Fig. 6). As soon as the $30 \%$ RH is set, all composites continue to uptake water during the entire hydration period. However, all solids except SCa4 and pure salt exhibited a general adsorption behaviour i.e., the rate of water uptake is higher during the initial phase of hydration (until $\sim 40000 \mathrm{~s}$ ) and then it started to decrease until they are almost saturated by water vapour and begins to exhibit a plateau in adsorption curves (Fig. 6). However, the saturation due to equilibrium hydration was not attained in this study compared to previously reported $\mathrm{CaCl}_{2}$

composites. ${ }^{13,28}$ This is due to the presence of higher $\mathrm{CaCl}_{2}$ content in our composites that can result in decreased rate (or kinetics) and/or the lower RH employed in our study. 


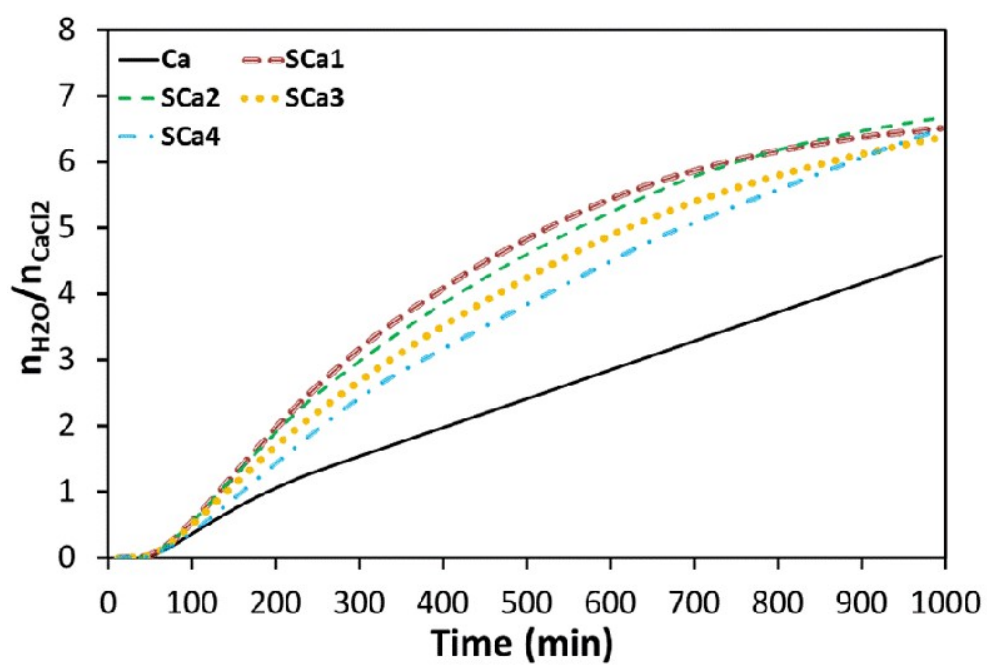

Figure 6. Normalized water sorption as a function of time for all solids during second hydration cycle at $25^{\circ} \mathrm{C}, 1 \mathrm{~atm}$ and $30 \% \mathrm{RH}$

Since, three (di-, tetra- and hexa-) stable intermediate $\mathrm{CaCl}_{2}$ phases are generally formed during the hydration of an anhydrous $\mathrm{CaCl}_{2}$ salt as indicated above, the time taken for the composites to attain these three hydrated forms are reported in Table 5. This time required for the hydration of anhydrous $\mathrm{CaCl}_{2}$ also corresponds to the rate of water adsorption that varied from one composite to other (Fig. 6 and Table 5). The water sorption rate of pure anhydrous $\mathrm{CaCl}_{2}$ salt is much lower as it took 400 min and 852 min to reach the $\mathrm{CaCl}_{2} \cdot 2 \mathrm{H}_{2} \mathrm{O}$ and $\mathrm{CaCl}_{2} \cdot 4 \mathrm{H}_{2} \mathrm{O}$ phases respectively i.e., around $150-340$ min more time compared to the $\mathrm{SCa} 4$ with least water adsorption rate among all composites (Table 5). Also, commercial $\mathrm{CaCl}_{2}$ salt could not attain a hexahydrate phase even after 960 min of hydration period (Fig. 6 and Table 5). The time taken for the composites to attain any successive hydrated $\mathrm{CaCl}_{2}$ phase is of the order: $\mathrm{SCa} 4>\mathrm{SCa} 3>\mathrm{SCa} 2>$ SCa1. Hence, the water adsorption rate is highest in non-functionalized SCa1 and least in CES $\left(\mathrm{COO}^{-}\right)$functionalized $\mathrm{SCa} 4$ while $\mathrm{HMDS}\left(-\mathrm{CH}_{3}\right)$ functionalized $\mathrm{SCa} 2$ and $\mathrm{SCa} 3$ composites exhibited intermediate water sorption rates. In all composites irrespective of their functionalization or extent of pore filling, the rate of water sorption remained rather steady 
during the successive hydration of anhydrous $\mathrm{CaCl}_{2}$ to $\mathrm{CaCl}_{2} \cdot 2 \mathrm{H}_{2} \mathrm{O}$ phases, to form $\mathrm{CaCl}_{2} \cdot 4 \mathrm{H}_{2} \mathrm{O}$ phase and then decreased for further hydration to form $\mathrm{CaCl}_{2} \cdot 6 \mathrm{H}_{2} \mathrm{O}$ phase.

Table 5. Hydration rate and kinetic rate constant of pure $\mathrm{CaCl}_{2}$ and composite solids.

\begin{tabular}{|c|c|c|c|c|c|}
\hline \multirow{2}{*}{ Solids } & \multicolumn{3}{|c|}{$\begin{array}{l}\text { Total time taken during hydration cycle to } \\
\text { attain }\end{array}$} & \multirow{2}{*}{$* \mathrm{k}\left(\mathrm{s}^{-1}\right)$} & \multirow{2}{*}{$\mathbf{R}^{2}$} \\
\hline & $\begin{array}{c}\mathrm{CaCl}_{2} \cdot 2 \mathrm{H}_{2} \mathrm{O} \\
\text { (min) }\end{array}$ & $\begin{array}{l}\mathrm{CaCl}_{2} \cdot 4 \mathrm{H}_{2} \mathrm{O} \\
(\min )\end{array}$ & $\begin{array}{l}\mathrm{CaCl}_{2} \cdot 6 \mathrm{H}_{2} \mathrm{O} \\
(\min )\end{array}$ & & \\
\hline SCa1 & 200 & 390 & 700 & $6.96 \times 10^{-5}$ & 0.99 \\
\hline SCa2 & 211 & 421 & 740 & $6.58 \times 10^{-5}$ & 0.99 \\
\hline SCa3 & 226 & 464 & 850 & $6.40 \times 10^{-5}$ & 0.99 \\
\hline SCa4 & 250 & 515 & 890 & $5.68 \times 10^{-5}$ & 0.99 \\
\hline $\mathrm{Ca}$ & 400 & 852 & $>960$ & $3.50 \times 10^{-5}$ & 0.98 \\
\hline
\end{tabular}

*Rate constant obtained from the slope of the curves derived from long term region of Fickian model

In order to study the detailed kinetic characteristics of the solids, the Fickian rate constant (k) and the solid conversion rate $(\mathrm{d} \alpha / \mathrm{dt})$ were determined. Assuming that the hydration mechanism in the composites is controlled by the intra-particle diffusion, the Fickian's second law corresponding to the long-term region can be expressed by the simplified formulae:

$$
\left(1-\frac{m_{t}}{m_{\infty}}\right)=\frac{6}{\pi^{2}} \exp (-k t)
$$

where $\mathrm{m}_{\mathrm{t}}=$ amount of water adsorbed $\left(\mathrm{g}_{\mathrm{H} 2 \mathrm{O}} \cdot \mathrm{g}_{\text {solid }}{ }^{-1}\right)$ at time $>0$, and $\mathrm{m}_{\infty}=$ amount of water adsorbed $\left(\mathrm{g}_{\mathrm{H} 2 \mathrm{O}} \cdot \mathrm{g}_{\mathrm{solid}}{ }^{-1}\right)$ at $\mathrm{t}=^{\mathrm{k}}$'respectively, $\mathrm{k}=$ rate constant $\left(\mathrm{s}^{-1}\right)$ of water adsorption process that is calculated using the formulae: $k=\frac{\pi^{2} D}{R_{p}^{2}}\left(\mathrm{D}=\right.$ effective diffusivity $\left(\mathrm{m}^{2} \cdot \mathrm{s}^{-1}\right), \mathrm{R}_{\mathrm{p}}=$ particle radius). 
Though both short-term and long-term diffusion regions can exist simultaneously, only longterm region $\left(\frac{m_{t}}{m_{\infty}}>0.6\right)$ was observed in this study in agreement with previously reported $\mathrm{CaCl}_{2}$ silica gel composite. ${ }^{13}$ The rate constant $(\mathrm{k})$ for the water uptake can thus be determined from the slope of $\ln \left(1-\frac{m_{t}}{m_{\infty}}\right) v s$ time plots for all composites and are reported in Table 5. A good fit with $\mathrm{R}^{2}$ value close to 1 is obtained for the plots of all composites depicting that the intra-particle diffusion is an important factor controlling the water sorption kinetics of the $\mathrm{SBA}-\mathrm{CaCl}_{2}$ composites used in this study (Table 5 \& Fig. S7).

The rate constant $(\mathrm{k})$ of the water adsorption process for the composites is of the order: SCa1 > $\mathrm{SCa} 2>\mathrm{SCa} 3>\mathrm{SCa} 4>\mathrm{Ca}$. This follows a reverse trend compared to the time taken to successively hydrate $\mathrm{CaCl}_{2}$ phases as expected (Table 5). Hence, the pure $\mathrm{CaCl}_{2}$ salt that required more time and the $\mathrm{SCa} 1$ that required least time for successive hydration of $\mathrm{CaCl}_{2}$ phases exhibited the lowest $\left(3.50 \times 10^{-5}\right)$ and the highest $\left(6.96 \times 10^{-5}\right)$ ' $\mathrm{k}$ ' values respectively. The lower rate constant of commercial $\mathrm{CaCl}_{2}$ is due to the low water mobility in the bulk phase of pure salt compared to composites with well dispersed salt in their pores. However, the order of rate constant is still $10^{-5} \mathrm{~s}^{-1}$ for both pure $\mathrm{CaCl}_{2}$ and composites indicating the fact that it is rather the intrinsic reaction of the salt particles and water that mainly influences the rate of water sorption/diffusion than the mobility of water through the composite pores. ${ }^{31}$ The rate constants of the HMDS functionalized SCa2 $\left(6.58 \times 10^{-5}\right)$ and SCa3 $\left(6.40 \times 10^{-5}\right)$ composites are slightly lower than that of non-functionalized SCa1 composite $\left(6.96 \times 10^{-5}\right)$ suggesting that methyl functionalization has some influence on the intra-particular diffusion through the composites. However, the rate constant of CES functionalized SCa4 is lower $\left(5.68 \times 10^{-5}\right)$ than all composites because of the presence of considerable amount of bulk-like $\mathrm{CaCl}_{2}$ phase that rest on the external surface of this composite. The rate constant values obtained in this work are in the order of $10^{-5}$ 
$\mathrm{s}^{-1}$ that is close to the value reported previously for silica gel- $\mathrm{CaCl}_{2}$ composite hydrated at similar conditions. ${ }^{13}$ However, the ' $\mathrm{k}$ ' value of the $\mathrm{SBA}-15 / \mathrm{CaCl}_{2}$ composites is almost 10 times lower than reported for encapsulated $\mathrm{CaCl}_{2}$ solids possibly due to the higher relative humidity $\mathrm{RH} \sim$ $56 \%)$ employed in that study compared to this work $(\mathrm{RH}=30 \%){ }^{28}$

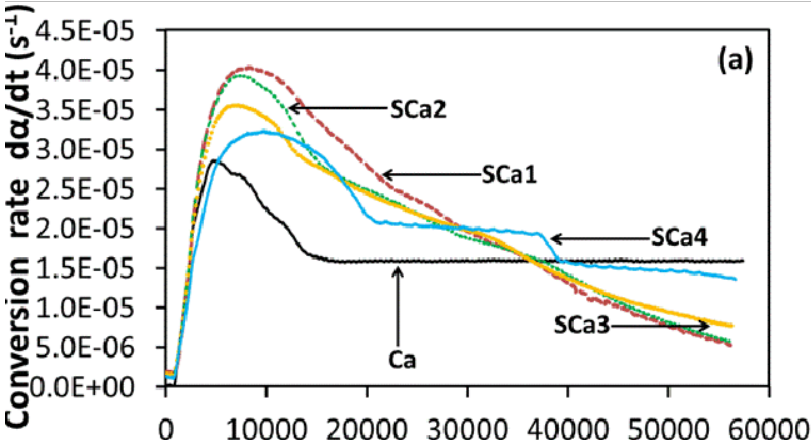

Time (s)

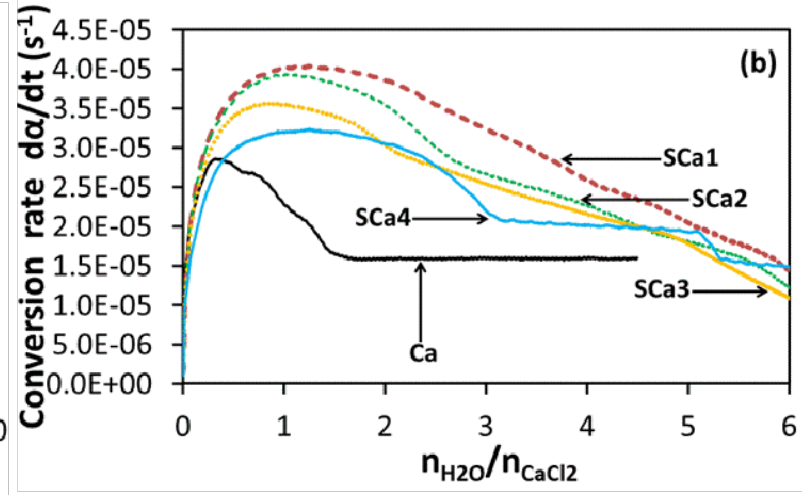

Figure 7. Conversion rate as a function of (a) time and (b) normalized water uptake (moles of $\mathrm{H}_{2} \mathrm{O}$ adsorbed per mol of $\mathrm{CaCl}_{2}$ ) for all solids during second hydration cycle at $25^{\circ} \mathrm{C}, 1 \mathrm{~atm}$ and $30 \% \mathrm{RH}$

The conversion rate $(\mathrm{d} \alpha / \mathrm{dt})$ of the solids was determined as this kinetic parameter is directly associated with the changes in the sample mass during the hydration cycle. It is also an indirect representation of the hydration rate of solids. The conversion $(\alpha)$ is calculated from the solid masses measured in TGA according to the formulae:

$$
\alpha=\frac{m_{t}-m_{i}}{m_{f}-m_{i}}
$$

where $\mathrm{m}_{\mathrm{t}}=$ mass of solid at time ' $\mathrm{t}$ ', $\mathrm{m}_{\mathrm{i}}=$ initial mass of solid and $\mathrm{m}_{\mathrm{f}}=$ final mass of solid. ${ }^{28}$ The minimum value of conversion is zero for the dried solid before hydration begins and maximum value at the end of hydration will be unity.

Figure 7 shows conversion rate of the solids as a function of time and normalized amount of water adsorbed. For pure salt, after attaining a maximum of $2.84 \times 10^{-5} \mathrm{~s}^{-1}$ at $\sim 5000 \mathrm{~s}$, the conversion rate decreases rapidly to $1.58 \times 10^{-5} \mathrm{~s}^{-1}$ and then remained steady at this rate until the 
end of hydration cycle. During hydration, the conversion rates of the composites increase and reach maximum at around $7500-8000 \mathrm{~s}$ after which the rates start to decrease gradually. For all composites, the maximum conversion rate is almost attained at the $\mathrm{nH}_{2} \mathrm{O} / \mathrm{nCaCl}_{2}$ ratio of $\sim 1$ (Fig. 7b). The conversion rates of all composites then remain rather steady (negligible decrease) at their maxima until the $\mathrm{nH}_{2} \mathrm{O} / \mathrm{nCaCl}_{2}$ ratio of $\sim 2$. While the rate decreases rather steadily until the formation of $\mathrm{CaCl}_{2} \cdot 6 \mathrm{H}_{2} \mathrm{O}$ phase for non-functionalized $\mathrm{SCa} 1$, the decrease in the conversion rate occurs in three steps (small change in slope at $\mathrm{nH}_{2} \mathrm{O} / \mathrm{nCaCl}_{2} \sim 3 \& 5$ in Fig. 7 b) for the HMDS functionalized SCa2 and SCa3 composites. Also, the conversion rate curves of SCa2 and $\mathrm{SCa} 3$ remained always inferior to $\mathrm{SCa} 1$ till the $\mathrm{CaCl}_{2} \cdot 6 \mathrm{H}_{2} \mathrm{O}$ phase is formed. As the conversion rate $\left(1.58 \times 10^{-5} \mathrm{~s}^{-1}\right)$ of SCa4 composite during this steady phase perfectly coincides with the conversion rate of pure $\mathrm{CaCl}_{2}$ salt, the final steady conversion rate in $\mathrm{SCa} 4$ could be assigned to some bulk $\mathrm{CaCl}_{2}$ particles accumulated on its external surface. The maximum conversion rate of the composites is of the order: $\mathrm{SCa} 1>\mathrm{SCa} 2>\mathrm{SCa} 3>\mathrm{SCa} 4>\mathrm{Ca}$ which is in good agreement with the order of rate constants determined by the Fickian model. Hence, use of conversion rate to determine the kinetic characteristics of the solids helped to reaffirm the decreased water sorption rate and slow hydration kinetics of $\mathrm{SCa} 4$ composite and pure $\mathrm{CaCl}_{2}$ salt compared to other composites.

As a partial conclusion, the non-functionalized composite (SCa1) showed better water sorption kinetics, in terms of Fickian rate constant $(\mathrm{k})$ and solid conversion rate (d $\alpha / \mathrm{dt})$, compared to all functionalized composites. Though HMDS functionalization only resulted in slight decrease in the hydration rate of the $\mathrm{SCa} 2$ and $\mathrm{SCa} 3$ composites, the CES functionalized $\mathrm{SCa} 4$ exhibited considerable reduction in the water sorption kinetics because of the presence of bulk $\mathrm{CaCl}_{2}$ phase on $\mathrm{SCa} 4$ surface. 


\subsubsection{Stability of the composite as TCHS material}

In order to determine the stability of the composite, five dehydration/hydration cycles were performed with SCa1 composite that exhibited comparatively better performance in this study. During all five hydration cycles, $\mathrm{SCa} 1$ attained same weight gain corresponding to the formation of $\mathrm{CaCl}_{2} \cdot 6.3 \mathrm{H}_{2} \mathrm{O}$ hydrated phase depicting the stable water adsorption capacity of the composite. Moreover, the enthalpy of hydration of SCa1 remains unchanged at $317 \pm 6 \mathrm{~kJ} \cdot \mathrm{mol}^{-1} \mathrm{CaCl}_{2}$ for five consecutive cycles confirming the stable TCHS behaviour of the solid (Fig. 8a). The DSC curves obtained for the five successive dehydration cycles with SCa1 is shown in Fig. S8. The DSC curves of all cycles except cycle 1 (conditioning step) coincide and the enthalpy of dehydration

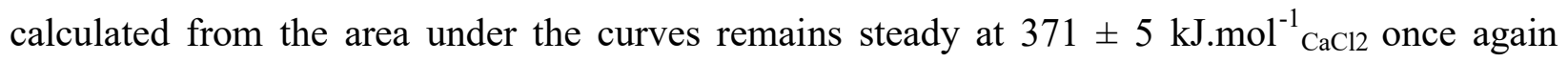
confirming the stability in the heat storage capacity of the solid. The rate constant values

calculated from long-term region Fickian model remained same at around $7 \pm 0.15 \times 10^{-5} \mathrm{~s}^{-1}$ for all hydration cycles indicating that the hydration kinetics of SCa1 also remains unaltered. 

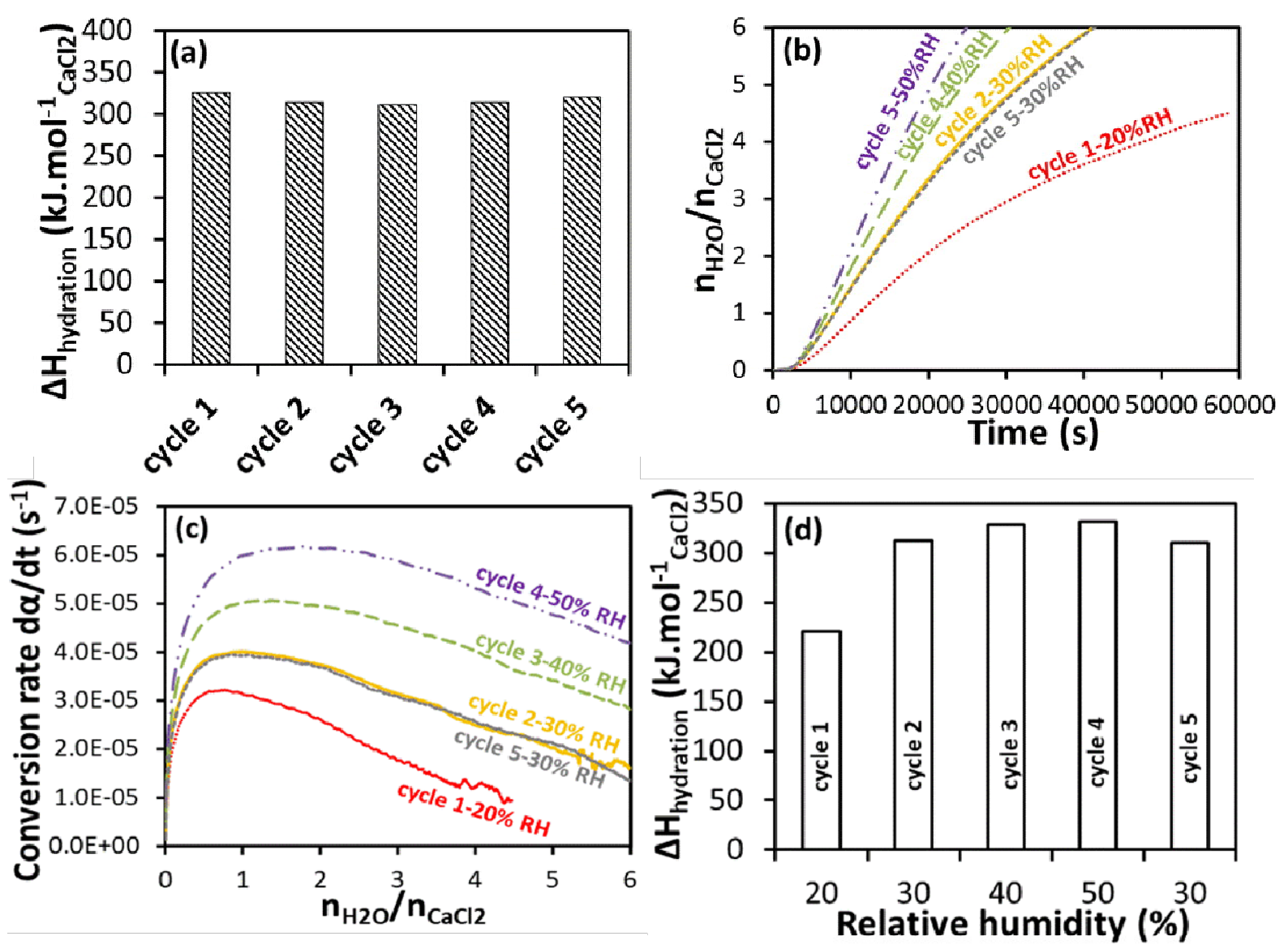

Figure 8. (a) Enthalpy of hydration of solids for five successive hydration cycles; (b)

Normalized water uptake; (c) Conversion rate of SCa1 during five successive hydration cycles performed by varying $\mathrm{RH}$ at $25^{\circ} \mathrm{C}$ and $1 \mathrm{~atm}$; (d) Enthalpy of hydration of SCa1 for five hydration cycles performed by varying $\mathrm{RH}$ at $25^{\circ} \mathrm{C}$ and $1 \mathrm{~atm}$. (Relative standard deviation of the enthalpy value is $\pm 4 \mathrm{~kJ} \cdot \mathrm{mol}^{-1} \mathrm{CaCl}$ )

Further, to study the influence of relative humidity on hydration and heat storage characteristics of the composite, five consecutive dehydration-hydration cycles have been conducted with SCa1. While, the dehydration protocols remain unchanged for all cycles, the five successive hydration steps were performed at $\mathrm{RH}$ of $20 \%, 30 \%, 40 \%, 50 \%$ and $30 \%$ (reversibility test) respectively. Figure $8 \mathrm{~b}$ shows that the normalized water uptake $\left(\mathrm{nH}_{2} \mathrm{O} / \mathrm{nCaCl}_{2}\right)$ increases with increase in the relative humidity during hydration period. The weight gain (extent of hydration) remains higher at higher relative humidity during the entire hydration period of SCa1. The maximum 
$\mathrm{nH}_{2} \mathrm{O} / \mathrm{nCaCl}_{2}$ values attained by SCa1 at an $\mathrm{RH}$ of $20 \%, 30 \%, 40 \%$ and $50 \%$ are $4.4,6.3,8.2$ and 9.8 respectively which clearly depicts that after $16 \mathrm{~h}$ of hydration at relative humidities $>30 \%$ the salt exists in solution inside the TGA crucible as mentioned above (Fig. $8 b$ ) ${ }^{28}$ Therefore, a maximum weight gain up to which the $\mathrm{CaCl}_{2}$ salt remains as solid i.e., the weight corresponding to the $\mathrm{CaCl}_{2} \cdot 6 \mathrm{H}_{2} \mathrm{O}$, is used to study the water sorption kinetics and heat storage behaviour of the solids for $\mathrm{RH}>30 \%$ (Figs. $8 \mathrm{c} \& 8 \mathrm{~d}$ ). It is evident from the Fig. $8 \mathrm{~b}$ that the rate of water adsorption is much higher for hydration cycle performed at higher RH as it took only $25000 \mathrm{~s}$ for the composite to attain $\mathrm{CaCl}_{2} \cdot 6 \mathrm{H}_{2} \mathrm{O}$ phase at $50 \% \mathrm{RH}$ compared to $40000 \mathrm{~s}$ at $30 \% \mathrm{RH}$. In order to have an insight on the hydration kinetics of SCal at different $\mathrm{RH}$, the solid conversion rate, which is an indirect representation of hydration rate, is determined as shown in Fig. 8c. During the entire period of hydration, the conversion rate of SCa1 is higher at higher relative humidity, for example, conversion rate is almost double at $50 \% \mathrm{RH}\left(6.12 \times 10^{-5} \mathrm{~s}^{-1}\right)$ compared to that at $20 \% \mathrm{RH}\left(3.11 \times 10^{-5} \mathrm{~s}^{-1}\right)$. Hence, at varying relative humidities, the hydration rate of SCa1 follows the order: $20 \% \mathrm{RH}>30 \% \mathrm{RH}>40 \% \mathrm{RH}>50 \% \mathrm{RH}$. Further, to verify the reversibility and reproducibility in the water sorption behaviour of SCa1 after the formation of aqueous solution at high $\% \mathrm{RH}$, a final $\left(5^{\text {th }}\right)$ hydration cycle was performed after returning to $30 \%$ RH. It is clear from the Fig. $8 \mathrm{~d}$ that the water uptake and conversion rate during cycle 5 follows the same path as of cycle 2 performed at $30 \% \mathrm{RH}$ demonstrating that the water sorption behaviour of the SCa1 composite is reversible and reproducible without any loss in its hydration ability.

Hydration enthalpy values of SCa1 at $\mathrm{RH}>30 \%$ were determined by the parallel integration of DSC curves until the formation of $\mathrm{CaCl}_{2} \cdot 6 \mathrm{H}_{2} \mathrm{O}$ phase $\left(\mathrm{nH}_{2} \mathrm{O} / \mathrm{nCaCl}_{2}=6\right)$ (Fig. $\left.8 \mathrm{~d}\right) . \Delta \mathrm{H}_{\text {hydration }}$ increased considerably when the RH is increased from $20 \%\left(220 \mathrm{~kJ}^{\left.-\mathrm{mol}^{-1} \mathrm{CaCl}\right)}\right)$ to $30 \%(315$ 
$\left.\mathrm{kJ} \cdot \mathrm{mol}^{-1} \mathrm{CaCl} 2\right)$. Further increase of $\mathrm{RH}$ from $30 \%$ to $50 \%$ showed only negligible increase in the enthalpy suggesting that the maximum heat storage capacity of SCa1 is attained at around $30 \%$ $\mathrm{RH}$ in the conditions employed in this study.

\section{Conclusions}

The methyl- and carboxyl- groups functionalized SBA- $15 / \mathrm{CaCl}_{2}$ composites with high $\mathrm{CaCl}_{2}$ content ( $\sim 60 \mathrm{wt} . \%)$ have been successfully synthesized. The textural characterization confirmed the fact that even after addition of large amount $(\sim 60 \mathrm{wt} . \%)$ of $\mathrm{CaCl}_{2}$, the composites retained their ordered mesoporous texture and the salt particles are well dispersed in the mesopores of all composites except SCa4 that showed the presence of large crystalline $\mathrm{CaCl}_{2}$ particles on its surface.

The DSC peaks of the composites during the dehydration cycle shifted to lower temperatures compared to pure salt suggesting the increased dehydration rate of the composites due to the well dispersed $\mathrm{CaCl}_{2}$ particles in the silica mesopores. Moreover, the water sorption behaviour (reversibility and hydration rate) of the commercial $\mathrm{CaCl}_{2}$ improved considerably after its incorporation into a mesoporous SBA-15. The rate of water sorption is highest in nonfunctionalized $\mathrm{SCa} 1$ and least in $\mathrm{CES}\left(\mathrm{COO}^{-}\right)$functionalized $\mathrm{SCa} 4$ while $\mathrm{HMDS}\left(-\mathrm{CH}_{3}\right)$ functionalized $\mathrm{SCa} 2$ and $\mathrm{SCa} 3$ composites exhibited intermediate water sorption rates. The Fickian rate constant $(\mathrm{k})$ and the conversion rate $(\mathrm{d} \alpha / \mathrm{dt})$ determined for the hydration cycle demonstrated that the water sorption rate in the composites follows the order: $\mathrm{SCa} 1>\mathrm{SCa} 2>$

$\mathrm{SCa} 3>\mathrm{SCa} 4>\mathrm{Ca}$. The lower rate constant of commercial $\mathrm{CaCl}_{2}$ is due to the low water mobility in the bulk phase of pure salt compared to composites with well dispersed salt in their mesopores. The kinetic study suggested that the rate of water sorption/diffusion is mostly 
affected by the intrinsic reaction between salt particles and water rather than the mobility of water through the pores. Heat storage capacities $\left(\Delta \mathrm{H}_{\text {hydration }}\right.$ per mol of $\left.\mathrm{CaCl}_{2}\right)$ of the composites follow the similar order as water sorption: $\mathrm{SCa} 1>\mathrm{SCa} 2>\mathrm{SCa} 3 \sim \mathrm{SCa} 4$. Stability tests performed using the better performing non-functionalized SCa1 exhibited steady heat storage capacity $\left(\sim 317 \pm 6 \mathrm{~kJ} \cdot \mathrm{mol}^{-1} \mathrm{CaCl}_{2}\right)$ and hydration rate $\left(7 \pm 0.15 \times 10^{-5} \mathrm{~s}^{-1}\right)$ for five successive hydration cycles at $30 \% \mathrm{RH}$.

\section{ASSOCIATED CONTENT}

Supporting Information. Figure S1. Infrared spectra of (a) SBA-15, SBA-HMDS and SBACES and (b) SCa composites between $600-2200 \mathrm{~cm}^{-1}$ range Figure S2. ${ }^{13} \mathrm{C}$ NMR of SBA-CES and SCa4. Figure S3. Elemental EDX mapping images of SCa1. Figure S4. TGA curves of composites during first dehydration cycle. Figure S5. Integration of the DSC curve obtained during the hydration cycle 2 with SCa4 (Red colored area is used to calculate the enthalpy value). Figure S6: (a) Comparison of dehydration / hydration enthalpy values of solids during the second sorption cycle. (b): Enthalpy of hydration of solids during two successive hydration cycles. Figure S7. Experimental and linear fitted rehydration curves of composites and pure $\mathrm{CaCl}_{2}$ for long-term region intraparticle diffusion. Figure S8. DSC curves for the five successive dehydration cycles with SCa1.

\section{AUTHOR INFORMATION}

Corresponding Author

* Phone: +33 4724481 66, e-mail : laurence.bois@univ-lyon1.fr

Author Contributions 
The manuscript was written through contributions of all authors. All authors have given approval to the final version of the manuscript.

Funding Sources

This work was supported by the LABEX iMUST (ANR-10-LABX-0064) of the Université de Lyon, within the program "Investing in the Future" (ANR-11-IDEX-0007) by the French National Research Agency (ANR).

\section{ACKNOWLEDGMENT}

The authors gratefully acknowledge the $\mathrm{Ct} \mu$ platform of electronic microscopy (University Lyon 1). Chantal Lorentz (IRCELYON) is also gratefully acknowledged for the NMR experiments.

\section{REFERENCES}

[1] https://www.c2es.org/content/renewable-energy/ 09/2020

[2] http://solarenergyfactsblog.com/how-much-solar-energy-is-used-in-the-world/ 09/2020

[3] Jarimi, H.; Aydin D.; Yanan Z.; Ozankaya G.; Chen X.; Riffat, S. Review on the recent progress of thermochemical materials and processes for solar thermal energy storage and industrial waste heat recovery, Int. J. Low-Carbon Technol. 2019, 14, 44-69. https://doi.org/10.1093/ijlct/cty052

[4] Feng, C. Jiaqiang, E.; Han, W.; Deng, Y.; Zhang, B. Key technology and application analysis of zeolite adsorption for energy storage and heat-mass transfer process: A review, Renewable and Sustainable Energy Reviews, 2021, 144, 110954. https://doi.org/10.1016/j.rser.2021.11095.

[5] N'Tsoukope, K.E.; Kuznik, F. A reality check on long-term thermochemical heat storage for household applications, Renewable \& Sustainable Energy Rev., 2021, 139, 11068. https://doi.org/10.1016/j.rser.2020.110683 
[6] Posern, K.; Kaps, Ch. Calorimetric studies of thermochemical heat storage materials based on mixtures of $\mathrm{MgSO}_{4}$ and $\mathrm{MgCl}_{2}$, Thermochim. Acta, 2010, 502, 73-76. https://doi.org/10.1016/j.tca.2010.02.009

[7] Donkers, P.A.J.; Sögütoglu, L.C.; Huinink, H.P.; Fischer, H.R.; Adan, O.C.G. A review of salt hydrates for seasonal heat storage in domestic applications, Applied Energy, 2017, 199, 45, 68. https://doi.org/10.1016/j.apenergy.2017.04.080

[8] Clark, R.J.; Abbas Mehrabadi, A.; Farid, M. State of the art on salt hydrate thermochemical energy storage systems for use in building applications, J. of Energy Storage, 2020, 27, 101145. https://doi.org/10.1016/j.est.2019.101145.

[9] Wu, H.; Salles, F.; Zajac, Z. A Critical Review of Solid Materials for Low-Temperature Thermochemical Storage of Solar Energy Based on Solid-Vapour Adsorption in View of Space Heating Uses, Molecules, 2019, 24(5), 945. https://doi.org/10.3390/molecules24050945

[10] Lin, J.; Zhao, Q.; Huang, H.; Mao, H.; Liu Y.; Xiao, Y. Applications of low-temperature thermochemical energy storage systems for salt hydrates based on material classification: A review, Sol. Energy, 2021, 214, 149-178. https://doi.org/10.1016/j.solener.2020.11.055

[11] Jabbari-Hichri, A.; Bennici, S.; Auroux, A. Enhancing the heat storage density of silicaalumina by addition of hygroscopic salts $\left(\mathrm{CaCl}_{2}, \mathrm{Ba}(\mathrm{OH})_{2}\right.$, and $\left.\mathrm{LiNO}_{3}\right)$, Sol. Energy Mater. Sol. Cells, 2015, 140, 351-360. https://doi.org/10.1016/j.solmat.2015.04.032

[12] Jabbari-Hichri, A.; Bennici, S.; Auroux, A. Effect of aluminum sulfate addition on the thermal storage performance of mesoporous SBA-15 and MCM-41 materials, Sol. Energy Mater. Sol. Cells, 2016, 149, 232-241. https://doi.org/10.1016/j.solmat.2016.01.033

[13] Jabbari-Hichri, A.; Bennici, S.; Auroux, A. $\mathrm{CaCl}_{2}$-containing composites as thermochemical heat storage materials, Sol. Energy Mater. Sol. Cells, 2017, 172, 177-185. https://doi.org/10.1016/j.solmat.2017.07.037

[14] Whiting, G.; Grondin, D.; Bennici, S.; Auroux, A. Heats of water sorption studies on zeolite- $\mathrm{MgSO}_{4}$ composites as potential thermochemical heat storage materials, Sol. Energy Mater. Sol. Cells, 2013, 112, 112-119. https://doi.org/10.1016/j.solmat.2013.01.020

[15] Permyakova, A. ; Wang, S. ; Courbon, E. ; Nouar, F. ; Heymans, N. ; D'Ans, P. ; Barrier, N.; Billemont, P. ; Weireld, G.D. ; Steunou, N. ; Frère, M. ; Serre, C. Design of salt-metal organic framework composites for seasonal heat storage applications, J. Mat. Chem. A 2017, 5, 12889-12898. https://doi.org/10.1039/C7TA03069J

[16] Brancato, V.; Calabrese, L.; Palomba,V. ;Frazzica, A.; Fullana-Puig, M.; Solé, A.; Cabeza, L.F. $\mathrm{MgSO}_{4} \cdot 7 \mathrm{H}_{2} \mathrm{O}$ filled macro cellular foams: An innovative composite sorbent for thermochemical energy storage applications for solar buildings, Solar Energy, 2018, 173, 1278-1286. https://doi.org/10.1016/j.solener.2018.08.075 
[17] Shkatulov, A.; Joosten, R.; Fischer, H.; Huinink, H. Core-Shell Encapsulation of Salt Hydrates into Mesoporous Silica Shells for Thermochemical Energy Storage, ACS Applied Energy Materials, 2020, 3, 7, 6860-6869. https://doi.org/10.1021/acs.cgd.8b01908

[18] Guo, L.; Gu, W.; Peng, C.; Wang, W.; Li, Y.J.; Zong, T.; Tang, Y.; Wu, Z.; Lin, Q.; Ge, M.; Zhang, G.; Hu, M.; Bi, X.; Wang, X.; Tang, M. A comprehensive study of hygroscopic properties of calcium- and magnesium- containing salts: implication for hygroscopicity of mineral dust and sea salt aerosols, Atmos. Chem. Phys. 2019, 19, 2115-2133. https://doi.org/10.5194/acp-19-2115-2019

[19] Yamaguchi, T.; Hayashi, S.; Ohtaki, H. X-ray diffraction study of calcium(II) chloride hydrate melts: $\mathrm{CaCl}_{2} \cdot \mathrm{RH}_{2} \mathrm{O}(\mathrm{R}=4.0,5.6,6.0$, and 8.6). Inorg. Chem. 1989, 28, 2434-2439. https://doi.org/10.1021/ic00311a036

[20] Karunadasa, K.S.P.; Manoratne, C.H.; Pitawala, H.M.T.G.A.; Rajapakse, R.M.G. Relative stability of hydrated/anhydrous products of calcium chloride during complete dehydration as examined by high-temperature X-ray powder diffraction, J. Phys.Chem. Solids, 2018, 120,167172. https://doi.org/ 10.1016/j.jpcs.2018.04.034

[21] Ushak, S.; Suárez, M.; Véliz, S.; Fernández, A.G.; Flores, E.; Galleguillos, H.R. Characterization of calcium chloride tetrahydrate as a phase change material and thermodynamic analysis of the results, Renew. Energy, 2016, 95, 213-224. https://doi.org/10.1016/j.renene.2016.04.012

[22] Molenda, M.; Stengler, J.; Linder, M.; Wörner, A. Reversible hydration behavior of $\mathrm{CaCl}_{2}$ at high $\mathrm{H}_{2} \mathrm{O}$ partial pressures for thermochemical energy storage, Thermochim. Acta, 2013, 560, 76-81. https://doi.org/10.1016/j.tca.2013.03.020

[23] Dawoud, B.; Aristov, Y. Experimental study on the kinetics of water vapor sorption on selective water sorbents, silica gel and alumina under typical operating conditions of sorption heat pumps, Int. J. Heat Mass Transfer, 2003, 46, 273-281. https://doi.org/10.1016/S00179310(02)00288-0

[24] Zheng, S.; Ge, T.S.; Wang R. Z.; Hu L.M. Performance study of composite silica gels with different pore sizes and different impregnating hygroscopic salts, Chem. Eng. Sci., 2014, 120, 19. https://doi.org/10.1016/j.ces.2014.08.047

[25] Zhu, D.; Wu, H.; Wang, S. Experimental study on composite silica gel supported $\mathrm{CaCl}_{2}$ sorbent for low grade heat storage, Int. J. Therm. Sci. 2006, 45, 804-813. https://doi.org/10.1016/j.ijthermalsci.2005.10.009

[26] Tso, C.Y.; Chao, C.Y.H. Activated carbon, silica-gel and calcium chloride composite adsorbents for energy efficient solar adsorption cooling and dehumidification systems, Int. J. Refrig. 2012, 35, 1626-1638. https://doi.org/10.1016/j.ijrefrig.2012.05.007

[27] Courbon, E.; D'Ans, P.; Permyakova, A.; Skrylnyk, O.; Steunou, N.; Degrez, M.; Frère, M. Further improvement of the synthesis of silica gel and $\mathrm{CaCl}_{2}$ composites: Enhancement of 
energy storage density and stability over cycles for solar heat storage coupled with space heating applications, Sol. Energy, 2017, 157, 532-541. https://doi.org/ 10.1016/j.solener.2017.08.034

[28] Gaeini, M. ; Rouws, A.L.; Salari, J.W.O.; Zondag, H.A.; Rindt, C.C.M. Characterization of microencapsulated and impregnated porous host materials based on calcium chloride for thermochemical energy storage, Appl. Energy, 2018, 212, 1165-1177. https://doi.org/10.1016/j.apenergy.2017.12.131

[29] Ristic, A.; Henninger, S.K. Sorption Composite Materials for Solar Thermal Energy Storage, Energy Procedia, 2014, 48, 977-981. https://doi.org/10.1016/j.egypro.2014.02.111

[30] Glaznev, I.; Ponomarenko, I.; Kirik, S.; Aristov, Y. Composites $\mathrm{CaCl}_{2} / \mathrm{SBA}-15$ for adsorptive transformation of low temperature heat: Pore size effect, Int. J. Refrig. 2011, 34, 1244-1250. https://doi.org/10.1016/j.ijrefrig.2011.02.007

[31] Ponomarenko, I.V.; Glaznev, I.S.; Gubar, A.V.; Kirik, S.D.; Aristov, Y.I. Synthesis and water sorption properties of a new composite " $\mathrm{CaCl}_{2}$ confined into SBA-15 pores", Microporous \& Mesoporous Mater. 2010; 129, 243-250. https://doi.org/10.1016/j.micromeso.2009.09.023

[32] Ristic, A.; Zabukovec Logar, N. New Composite Water Sorbents $\mathrm{CaCl}_{2}$-PHTS for LowTemperature Sorption Heat Storage: Determination of Structural Properties, Nanomaterials, 2019, 9, 27. https://doi.org/ 10.3390/nano9010027

[33] Li, Y.; Liu, Q.; Liu, Y.; Wang, D.; Chen, Y.; Liu, J. Calcium chloride hexahydrate/nano$\mathrm{SiO}_{2}$ composites as form-stable phase change materials for building energy conversation: The influence of pore size of nano-SiO 2 , Energy \& Buildings, 2020, 208, 109672. https://doi.org 10.1016/j.enbuild.2019.109672.

[34] Mitran, R.A.; Petrescu, S.; Somacescu, S.; Mocioiu, O.C.; Buhalteanu, L.; Berger, D.; Matei, C. Nanocomposite phase change materials based on $\mathrm{NaCl}-\mathrm{CaCl}_{2}$ and mesoporous silica, J. Therm. Anal. \& Calorim. 2019, 138, 2555-2563. https://doi.org/10.1007/s10973-019-08489

[35] Mitran, R-A.; Ionita, S.; Lincu, D.; Berger, D.; Matei, C. A Review of Composite Phase Change Materials Based on Porous Silica Nanomaterials for Latent Heat Storage Applications, Molecules, 2021, 26, 241. https://doi.org/10.3390/molecules26010241

[36] Janchen, J.; Ackermann, D.; Stach H.; Brosicke, W. Studies of the water adsorption on Zeolites and modified mesoporous materials for seasonal storage of solar heat, Solar Energy, 2004, 76, 339-344. https://doi.org/10.1016/j.solener.2003.07.036

[37] Aristov, Y.I.; Restuccia, G.; Cacciola, G.; Parmon, V.N. A family of new working materials for solid sorption air conditioning systems, Appl. Therm. Eng. 2002, 22, 191-204. https://doi.org/10.1016/S1359-4311(01)00072-2

[38] Gun'ko V.M.; Vedamuthu M.S.; Henderson G.L.; Blitz J.P. Mechanism and Kinetics of Hexamethyldisilazane Reaction with a Fumed Silica Surface, J. Colloid \& Interface Sci. 2000, 228,157-170. https://doi.org/10.1006/jcis.2000.6934 
[39] Zhao, D.; Feng, J.; Huo, Q.; Melosh, N.; Fredrickson, G.H.; Chmelka, B.F.; Stucky, G.D. Triblock Copolymer Syntheses of Mesoporous Silica with Periodic 50 to 300 Angstrom Pores, Science, 1998, 279, 548-552. https://doi.org/10.1126/science.279.5350.548

[40] Lyskawa, D.K.; Czaplicka, N.; Lapinski, M.; Koscielska, B.; Bray, F.; Precipitation and Transformation of Vaterite Calcium Carbonate in the Presence of Some Organic Solvents, Materials, 2020, 13(12), 2742. https://doi.org/ 10.3390/ma13122742

[41] Johnson, L.M.; Gao, L.; Shields, C.W.; Smith, M.; Efimenko, K.; Cushing, K., Genzer, J.; López, G.P. Elastomeric microparticles for acoustic mediated bioseparations, $J$. Nanobiotechnology, 2013, 11, 22. https://doi.org/10.1186/1477-3155-11-22

[42] Rodriguez-Blanco, J.D.; Shaw, S.; Benning, L.G. The kinetics and mechanisms of amorphous calcium carbonate (ACC) crystallization to calcite, via vaterite. Nanoscale, 2011, 3, 265-271. https://doi.org/10.1039/C0NR00589D

[43] Anderson, F.A.; Brecevic, L. Infrared Spectra of Amorphous and Crystalline Calcium Carbonate, Acta Chem. Scand., 1991, 45, 1018-1024. https://doi.org/10.3891/acta.chem.scand.45-1018

[44] Lu, Y.; Miller, J.D. Carboxyl Stretching Vibrations of Spontaneously Adsorbed and LBTransferred Calcium Carboxylates as Determined by FTIR Internal Reflection Spectroscopy, $J$ Colloid \& Interface Sci, 2002, 256, 41-52. https://doi.org/10.1006/jcis.2001.8112

[45] Roeges, N., A guide to the complete interpretation of Infrared Spectra of Organic Structures, Wiley; 1994, p. 1 - 340. https://www.wiley.com/en-us/9780471939986

[46] Nara, M.; Morii, H.; Tanokura, M. Coordination to divalent cations by calcium-binding proteins studied by FTIR spectroscopy, Biochim. Biophys. Acta Biomembr. 2013, 1828, 23192327. https://doi.org/ 10.1016/j.bbamem.2012.11.025

[47] Mizuguchi, M.; Nara, M.; Kawano, K.; Nitta, K. FT-IR study of the $\mathrm{Ca}^{2+}$-binding to bovine $\alpha$-lactalbumin: Relationships between the type of coordination and characteristics of the bands due to the Asp $\mathrm{COO}^{-}$groups in the $\mathrm{Ca}^{2+}$-binding site, FEBS Letters, 1997, 417, 153-156. https://doi.org/10.1016/S0014-5793(97)01274-X

[48] Sánchez-Salcedo, S.; Colilla, M.; Izquierdo-Barba, I.; Vallet-Regí, M. Design and preparation of biocompatible zwitterionic hydroxyapatite, J Mat. Chem. B, 2013, 1, 1595-1606. https://doi.org/ 10.1039/C3TB00122A

[49] Kondoh, A.; Oi, T. Interaction of Alkaline Earth Metal Ions with Carboxylic Acids in Aqueous Solutions studied by ${ }^{13} \mathrm{C}$ NMR Spectroscopy, Z. Naturforsch. A, 1998, 53, 77-91. https://doi.org/ 10.1515/zna-1998-1-212

[50] Bukovec, N.; Bukovec, P.; Arbanas, V. Tg and dsc investigation of $\mathrm{CaCl}_{2} \cdot 6 \mathrm{H}_{2} \mathrm{O}$, a phase change material for energy storage, Thermochim. Acta, 1989, 148, 281-288. https://doi.org/10.1016/0040-6031(89)85225-6 
[51] Tyagi, V.V.; Buddhi, D. Thermal cycle testing of calcium chloride hexahydrate as a possible PCM for latent heat storage, Sol. Energy Mater. Sol. Cells, 2008, 92, 891-899. https://doi.org/ 10.1016/j.solmat.2008.02.021 


\section{BRIEFS}

- SBA-15/CaCl 2 composites prepared using functionalized mesoporous silica and high salt content

- Water sorption and thermochemical heat storage capacities investigated by TGA/DSC

- Enhanced performance of composites due to well dispersed $\mathrm{CaCl}_{2}$ particles in SBA-15 mesopores

- Silica functionalization has significant influence on heat storage capacities of composites

- Water sorption rate is mainly affected by intrinsic reaction of salt and water

- SBA- $15 / \mathrm{CaCl}_{2}$ composite exhibited high and stable performance for five hydration cycles

\section{SYNOPSIS}

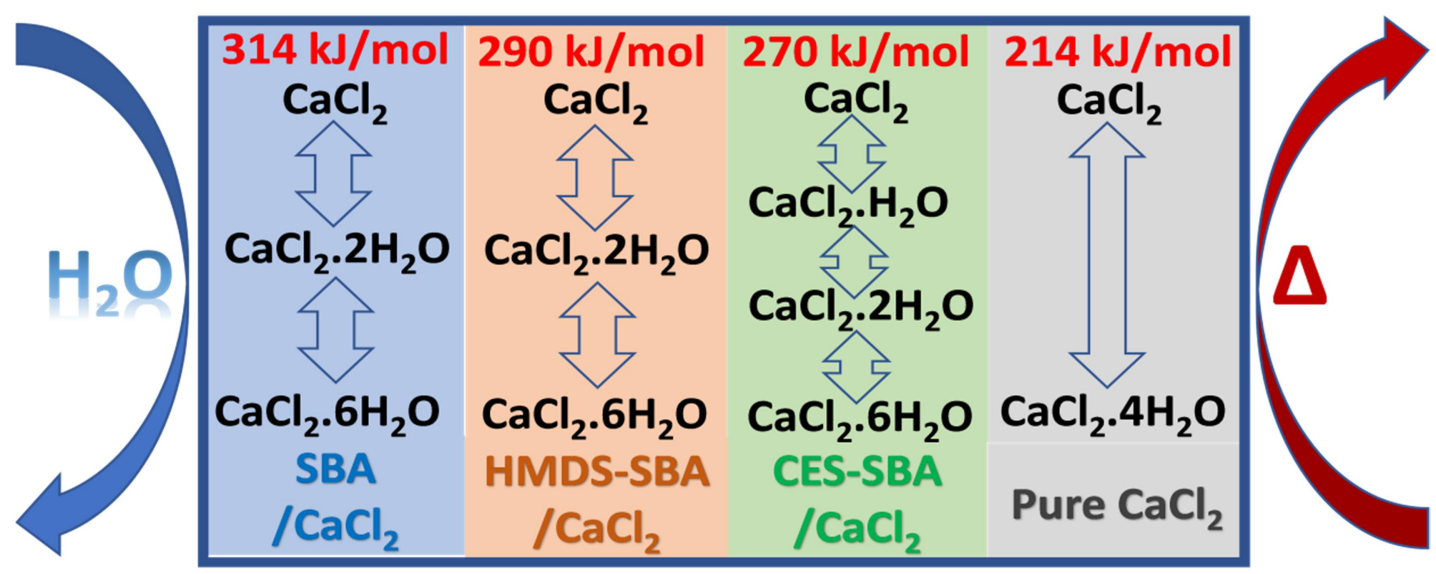

